4

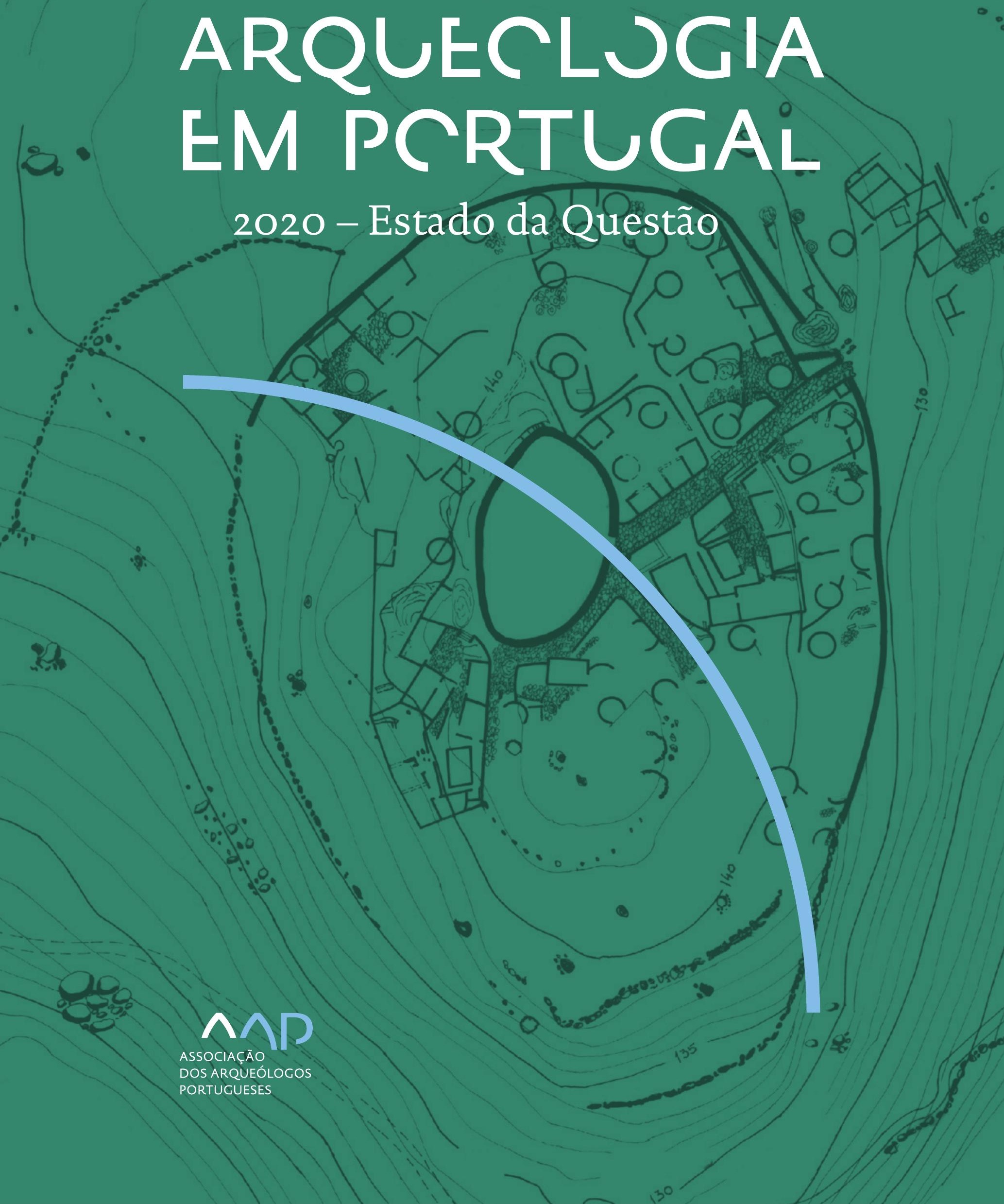


Coordenação editorial: José Morais Arnaud, César Neves e Andrea Martins Design gráfico: Flatland Design

AAP - ISBN: 978-972-9451-89-8

CITCEM - ISBN: 978-989-8970-25-1

Associação dos Arqueólogos Portugueses e CITCEM

Lisboa, 2020

O conteúdo dos artigos é da inteira responsabilidade dos autores. Sendo assim a Associação dos Arqueólogos Portugueses declina qualquer responsabilidade por eventuais equívocos ou questões de ordem ética e legal.

Desenho de capa:

Planta do castro de Monte Mozinho (Museu Municipal de Penafiel).

\section{$\hat{\wedge} \mathrm{P}$}

DOS ARQUEÓLOGOS PORTUGUESES

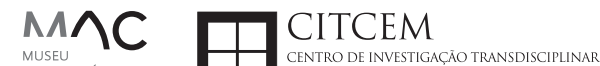
MUSEU
ARQUELLÓGICO
DO CARMO
U.PORTO

FLUP FACULDADE DE LETRAS
UNIVERSIDADE DO PORTO

Apoio

EC para a Ciência 


\section{Índice}

15 Prefácio

José Morais Arnaud

\section{Historiografia e Teoria}

17 Território, comunidade, memória e emoção: a contribuição da história da arqueologia (algumas primeiras e breves reflexões)

Ana Cristina Martins

25 Como descolonizar a arqueologia portuguesa?

Rui Gomes Coelho

41 Arqueologia e Modernidade: uma revisitação pessoal e breve de alguns aspetos da obra homónima de Julian Thomas de 2004

Vítor Oliveira Jorge

57 Dados para a História das Mulheres na Arqueologia portuguesa, dos finais do século XIX aos inícios do século XX: números, nomes e tabelas

Filipa Dimas / Mariana Diniz

73 Retractos da arqueologia portuguesa na imprensa: (in)visibilidades no feminino

Catarina Costeira / Elsa Luís

85 Arqueologia e Arqueólogos no Norte de Portugal Jacinta Bugalhão

101 Vieira Guimarães (1864-1939) e a arqueologia em Tomar: uma abordagem sobre o território e as gentes

João Amendoeira Peixoto / Ana Cristina Martins

115 Os memoráveis? A arqueologia algarvia na imprensa nacional e regional na presente centúria (2001-2019): características, visões do(s) passado(s) e a arqueologia

enquanto marca

Frederico Agosto / João Silva

129 A Evolução da Arqueologia Urbana e a Valorização Patrimonial no Barlavento Algarvio: Os casos de Portimão e Silves

Artur Mateus / Diogo Varandas / Rafael Boavida

\section{Gestão, Valorização e Salvaguarda do Património}

145 O Caderno Reivindicativo e as condições de trabalho em Arqueologia Miguel Rocha / Liliana Matias Carvalho / Regis Barbosa / Mauro Correia / Sara Simões / Jacinta Bugalhão / Sara Brito / Liliana Veríssimo Carvalho / Richard Peace / Pedro Peça / Cézer Santos

155 Os Estudos de Impacte Patrimonial como elemento para uma estratégia sustentável de minimização de impactes no âmbito de reconversões agrícolas Tiago do Pereiro

165 Salvaguarda de Património arqueológico em operações florestais: gestão e sensibilização Filipa Bragança / Gertrudes Zambujo / Sandra Lourenço / Belém Paiva / Carlos Banha / Frederico Tatá Regala / Helena Moura / Jacinta Bugalhão / João Marques / José Correia / Pedro Faria / Samuel Melro

179 Os valores do Património: uma investigação sobre os Sítios Pré-históricos de Arte Rupestre do Vale do Rio Côa e de Siega Verde José Paulo Francisco 
189 Conjugando recursos arqueológicos e naturais para potenciar as visitas ao Geoparque Litoral de Viana do Castelo (Noroeste de Portugal)

Hugo A. Sampaio / Ana M.S. Bettencourt / Susana Marinho / Ricardo Carvalhido

203 Áreas de Potencial Arqueológico na Região do Médio Tejo: Modelo Espacial Preditivo Rita Ferreira Anastácio / Ana Filipa Martins / Luiz Oosterbeek

223 Património Arqueológico e Gestão Territorial: O contributo da Arqueologia para a revisão do PDM de Avis

Ana Cristina Ribeiro

237 A coleção arqueológica do extinto Museu Municipal do Porto - Origens, Percursos e Estudos

Sónia Couto

251 Valpaços - uma nova carta arqueológica

Pedro Pereira / Maria de Fátima Casares Machado

263 Arqueologia na Cidade de Peniche

Adriano Constantino / Luís Rendeiro

273 Arqueologia Urbana: a cidade de Lagos como caso de Estudo Cátia Neto

285 Estratégias de promoção do património cultural subaquático nos Açores. O caso da ilha do Faial

José Luís Neto / José Bettencourt / Luís Borges / Pedro Parreira

297 Carta Arqueológica da Cidade Velha: Uma primeira abordagem

Jaylson Monteiro / Nireide Tavares / Sara da Veiga / Claudino Ramos / Edson Brito /

Carlos Carvalho / Francisco Moreira / Adalberto Tavares

311 Antropologia Virtual: novas metodologias para a análise morfológica e funcional Ricardo Miguel Godinho / Célia Gonçalves

\section{Didáctica da Arqueologia}

327 Como os projetos de Arqueologia podem contribuir para uma comunidade culturalmente mais consciente Alexandra Figueiredo / Claúdio Monteiro / Adolfo Silveira / Ricardo Lopes

337 Educação Patrimonial - Um cidadão esclarecido é um cidadão ativo! Ana Paula Almeida

351 A aproximação da Arqueologia à sala de aula: um caso de estudo no $3^{\circ}$ ciclo do Ensino Básico Luís Serrão Gil

363 Arqueologia 3.o - Pensar e comunicar a Arqueologia para um futuro sustentável Mónica Rolo

377 “Conversa de Arqueólogos" - Divulgar a Arqueologia em tempos de Pandemia Diogo Teixeira Dias

389 Escola Profissional de Arqueologia: desafios e oportunidades Susana Nunes / Dulcineia Pinto / Júlia Silva / Ana Mascarenhas

399 Os Museus de Arqueologia e os Jovens: a oferta educativa para o público adolescente Beatriz Correia Barata / Leonor Medeiros

411 O museu universitário como mediador entre a ciência e a sociedade: o exemplo da secção de arqueologia no Museu de História Natural e da Ciência da Universidade do Porto (MHNC-UP)

Rita Gaspar 
421 Museu de Lanifícios: Real Fábrica de Panos. Atividades no âmbito da Arqueologia Beatriz Correia Barata / Rita Salvado

427 Arqueologia Pública e o caso da localidade da Mata (Torres Novas) Cláudia Manso / Ana Rita Ferreira / Cristiana Ferreira / Vanessa Cardoso Antunes

431 Do sítio arqueológico ao museu: um percurso (também) didático Lídia Fernandes

447 Estão todos convidados para a Festa! E para dançar também... O projecto do Serviço Educativo do Museu Arqueológico do Carmo na $5^{\underline{a}}$ Edição da Festa da Arqueologia Rita Pires dos Santos

459 O “Clã de Carenque”, um projeto didático de arqueologia Eduardo Gonzalez Rocha

469 Mediação cultural: peixe que puxa carroça nas Ruínas Romanas de Troia Inês Vaz Pinto / Ana Patrícia Magalhães / Patrícia Brum / Filipa Santos

481 Didática Arqueológica, experiências do Projeto Mértola Vila Museu Maria de Fátima Palma / Clara Rodrigues / Susana Gómez / Lígia Rafael

\section{Arte Rupestre}

497 Os inventários de arte rupestre em Portugal Mila Simões de Abreu

513 O projeto FIRST-ART - conservação, documentação e gestão das primeiras manifestações de arte rupestre no Sudoeste da Península Ibérica: as grutas do Escoural e Maltravieso Sara Garcês / Hipólito Collado / José Julio García Arranz / Luiz Oosterbeek / António Carlos Silva / Pierluigi Rosina / Hugo Gomes / Anabela Borralheiro Pereira / George Nash / Esmeralda Gomes / Nelson Almeida / Carlos Carpetudo

523 Trabalhos de documentação de arte paleolítica realizados no âmbito do projeto PalæoCôa André Tomás Santos / António Fernando Barbosa / Luís Luís / Marcelo Silvestre / Thierry Aubry

537 Imagens fantasmagóricas, silhuetas elusivas: as figuras humanas na arte do Paleolítico Superior da região do Côa Mário Reis

$55^{1}$ Os motivos zoomórficos representados nas placas de tear de Vila Nova de São Pedro (Azambuja, Portugal) Andrea Martins / César Neves / José M. Arnaud / Mariana Diniz

571 Arte Rupestre do Monte de Góios (Lanhelas, Caminha). Síntese dos resultados dos trabalhos efectuados em 2007-2009 Mário Varela Gomes

599 Gravuras rupestres de barquiformes no Monte de S. Romão, Guimarães, Noroeste de Portugal Daniela Cardoso

613 Círculos segmentados gravados na Bacia do Rio Lima (Noroeste de Portugal): contributos para o seu estudo Diogo Marinho / Ana M.S. Bettencourt / Hugo Aluai Sampaio

631 Equídeos gravados no curso inferior do Rio Mouro, Monção (NW Portugal). Análise preliminar Coutinho, L.M. / Bettencourt, A.M.S / Sampaio, Hugo A.S

645 Paletas na Arte Rupestre do Noroeste de Portugal. Inventário preliminar Bruna Sousa Afonso / Ana M. S. Bettencourt / Hugo A. Sampaio 


\section{Pré-História}

661 O projeto Miño/Minho: balanço de quatro anos de trabalhos arqueológicos Sérgio Monteiro-Rodrigues / João Pedro Cunha-Ribeiro / Eduardo Méndez-Quintas / Carlos Ferreira / Pedro Xavier / José Meireles / Alberto Gomes / Manuel Santonja / Alfredo Pérez-González

677 A ocupação paleolítica da margem esquerda do Baixo Minho: a indústria lítica do sítio de Pedreiras 2 (Monção, Portugal) e a sua integração no contexto regional Carlos Ferreira / João Pedro Cunha-Ribeiro / Sérgio Monteiro-Rodrigues / Eduardo Méndez-Quintas / Pedro Xavier / José Meireles / Alberto Gomes / Manuel Santonja / Alfredo Pérez-González

693 O sítio acheulense do Plistocénico médio da Gruta da Aroeira Joan Daura / Montserrat Sanz / Filipa Rodrigues / Pedro Souto / João Zilhão

703 As sociedades neandertais no Barlavento algarvio: modelos preditivos com recurso aos SIG

Daniela Maio

715 A utilização de quartzo durante o Paleolítico Superior no território dos vales dos rios Vouga e Côa

Cristina Gameiro / Thierry Aubry / Bárbara Costa / Sérgio Gomes / Luís Luís / Carmen Manzano / André Tomás Santos

733 Uma perspetiva diacrónica da ocupação do concheiro do Cabeço da Amoreira (Muge, Portugal) a partir da tecnologia lítica Joana Belmiro / João Cascalheira / Célia Gonçalves

745 Novos dados sobre a Pré-história Antiga no concelho de Palmela. A intervenção arqueológica no sítio do Poceirão I

Michelle Teixeira Santos

757 Problemas em torno de Datas Absolutas Pré-Históricas no Norte do Alentejo Jorge de Oliveira

771 Povoamento pré-histórico nas áreas montanhosas do NO de Portugal: o Abrigo 1 de Vale de Cerdeira Pedro Xavier / José Meireles / Carlos Alves

783 Apreciação do povoamento do Neolítico Inicial na Baixa Bacia do Douro. A Lavra I (Serra da Aboboreira) como caso de estudo Maria de Jesus Sanches

797 O Processo de Neolitização na Plataforma do Mondego: os dados do Sector C do Outeiro dos Castelos de Beijós (Carregal do Sal)

João Carlos de Senna-Martinez / José Manuel Quintã Ventura / Andreia Carvalho / Cíntia Maurício

823 Novos trabalhos na Lapa da Bugalheira (Almonda, Torres Novas) Filipa Rodrigues / Pedro Souto / Artur Ferreira / Alexandre Varanda / Luís Gomes / Helena Gomes / João Zilhão

837 A pedra polida e afeiçoada do sítio do Neolítico médio da Moita do Ourives (Benavente, Portugal)

César Neves

857 Casal do Outeiro (Encarnação, Mafra): novos contributos para o conhecimento do povoamento do Neolítico final na Península de Lisboa.

Cátia Delicado / Carlos Maneira e Costa / Marta Miranda / Ana Catarina Sousa

873 Stresse infantil, morbilidade e mortalidade no sítio arqueológico do Neolítico Final/ Calcolítico ( $4^{\circ}$ e $3^{\circ}$ milénio a.C.) do Monte do Carrascal 2 (Ferreira do Alentejo, Beja) Liliana Matias de Carvalho / Sofia N. Wasterlain 
885 Come together: O Conjunto Megalítico das Motas (Monção, Viana do Castelo) e as expressões Campaniformes do Alto Minho Ana Catarina Basílio / Rui Ramos

899 Trabalhos arqueológicos no sítio Calcolítico da Pedreira do Poio Carla Magalhães / João Muralha / Mário Reis / António Batarda Fernandes

913 O sítio arqueológico de Castanheiro do Vento. Da arquitectura do sítio à arquitectura de um território João Muralha Cardoso

925 Estudo zooarqueológico das faunas do Calcolítico final de Vila Nova de São Pedro (Azambuja, Portugal): Campanhas de 2017 e 2018 Cleia Detry / Ana Catarina Francisco / Mariana Diniz / Andrea Martins / César Neves / José Morais Arnaud

943 As faunas depositadas no Museu Arqueológico do Carmo provenientes de Vila Nova de São Pedro (Azambuja): as campanhas de 1937 a 1967 Ana Catarina Francisco / Cleia Detry / César Neves / Andrea Martins / Mariana Diniz / José Morais Arnaud

959 Análise funcional de material lítico em sílex do castro de Vila Nova de S. Pedro (Azambuja, Portugal): uma primeira abordagem Rafael Lima

971 O recinto da Folha do Ouro 1 (Serpa) no contexto dos recintos de fossos calcolíticos alentejanos

António Carlos Valera / Tiago do Pereiro / Pedro Valério / António M. Monge Soares

\section{Proto-História}

987 Produção de sal marinho na Idade do Bronze do noroeste Português. Alguns dados para uma reflexão

Ana M. S. Bettencourt / Sara Luz / Nuno Oliveira / Pedro P. Simões / Maria Isabel C. Alves / Emílio Abad-Vidal

1001 A estátua-menir do Pedrão ou de São Bartolomeu do Mar (Esposende, noroeste de Portugal) no contexto arqueológico da fachada costeira de entre os rios Neiva e Cávado Ana M. S. Bettencourt / Manuel Santos-Estévez / Pedro Pimenta Simões / Luís Gonçalves

1015 O Castro do Muro (Vandoma/Baltar, Paredes) - notas para uma biografia de ocupação da Idade do Bronze à Idade Média

Maria Antónia D. Silva / Ana M. S. Bettencourt / António Manuel S. P. Silva / Natália Félix

1031 Do Bronze Final à Idade Média - continuidades e hiatos na ocupação de Povoados em Oliveira de Azeméis João Tiago Tavares / Adriaan de Man

1041 As faunas do final da Idade do Bronze no Sul de Portugal: leituras desde o Outeiro do Circo (Beja)

Nelson J. Almeida / Íris Dias / Cleia Detry / Eduardo Porfírio / Miguel Serra

1055 A Espada do Monte das Oliveiras (Serpa) - uma arma do Bronze Pleno do Sudoeste Rui M. G. Monge Soares / Pedro Valério / Mariana Nabais / António M. Monge Soares

1065 São Julião da Branca (Albergaria-a-Velha) - Investigação e valorização de um povoado do Bronze Final

António Manuel S. P. Silva / Paulo A. P. Lemos / Sara Almeida e Silva / Edite Martins de Sá

1083 Do castro de S. João ao Mosteiro de Santa Clara: notícia de uma intervenção arqueológica, em Vila do Conde Rui Pinheiro 
1095 O castro de Ovil (Espinho), um quarto de século de investigação - resultados e questões em aberto

Jorge Fernando Salvador / António Manuel S. P. Silva

1111 O Castro de Salreu (Estarreja), um povoado proto-histórico no litoral do Entre Douro e Vouga

Sara Almeida e Silva / António Manuel S. P. Silva / Paulo A. P. Lemos / Edite Martins de Sá

1127 Castro de Nossa Senhora das Necessidades (Sernancelhe): uma primeira análise artefactual Telma Susana O. Ribeiro

${ }_{1141}$ A cividade de Bagunte. O estado atual da investigação Pedro Brochado de Almeida

1153 Zoomorfos na cerâmica da Idade do Ferro no NW Peninsular: inventário, cronologias e significado Nuno Oliveira / Cristina Seoane

1163 Vasos gregos em Portugal: diferentes maneiras de contar a história do intercâmbio cultural na Idade do Ferro

Daniela Ferreira

1175 Os exotica da necrópole da Idade do Ferro do Olival do Senhor dos Mártires (Alcácer do Sal) no seu contexto regional

Francisco B. Gomes

\section{Antiguidade Clássica e Tardia}

1191 O uso de madeira como combustível no sítio da Quinta de Crestelos (Baixo Sabor): da Idade do Ferro à Romanização Filipe Vaz / João Tereso / Sérgio Simões Pereira / José Sastre / Javier Larrazabal Galarza / Susana Cosme / José António Pereira / Israel Espi

1207 Cultivos de Época Romana no Baixo Sabor: continuidade em tempos de mudança? João Pedro Tereso / Sérgio Simões Pereira / Filipe Santos / Luís Seabra / Filipe Vaz

1221 A casa romana na Hispânia: aplicação dos modelos itálicos nas províncias ibéricas Fernanda Magalhães / Diego Machado / Manuela Martins

1235 As pinturas murais romanas da Rua General Sousa Machado, n. ${ }^{5}$ 1, Chaves José Carvalho

1243 Trás do Castelo (Vale de Mir, Pegarinhos, Alijó) - Uma exploração agrícola romana do Douro

Tony Silvino / Pedro Pereira

1255 A sequência de ocupação no quadrante sudeste de Bracara Augusta: as transformações de uma unidade doméstica Lara Fernandes / Manuela Martins

1263 Os Mosaicos com decoração geométrica e geométrico-vegetalista dos sítios arqueológicos da área do Conuentus Bracaraugustanus. Novas abordagens quanto à conservação, restauro, decoração e datação Maria de Fátima Abraços / Licínia Wrench

1277 “Casa Romana” do Castro de São Domingos (Cristelos, Lousada): Escavação, Estudo e Musealização Paulo André de P. Lemos

1291 A arqueobotânica no Castro de Guifões (Matosinhos, Noroeste de Portugal): O primeiro estudo carpológico

Luís Seabra / Andreia Arezes / Catarina Magalhães / José Varela / João Pedro Tereso 
1305 Um Horreum Augustano na Foz do Douro (Monte do Castelo de Gaia, Vila Nova de Gaia) Rui Ramos

1311 Ponderais romanos na Lusitânia: padrões, formas, materiais e contextos de utilização Diego Barrios Rodríguez

1323 Um almofariz centro-itálico na foz do Mondego

Marco Penajoia

1335 Estruturas romanas de Carnide - Lisboa Luísa Batalha / Mário Monteiro / Guilherme Cardoso

1347 O contexto funerário do sector da "necrópole NO" da Rua das Portas de S. Antão (Lisboa): o espaço, os artefactos, os indivíduos e a sua interconectividade na interpretação do passado Sílvia Loja, José Carlos Quaresma, Nelson Cabaço, Marina Lourenço, Sílvia Casimiro, Rodrigo Banha da Silva, Francisca Alves-Cardoso

${ }_{1361}$ Povoamento em época Romana na Amadora - resultados de um projeto pluridisciplinar Gisela Encarnação / Vanessa Dias

1371 A Arquitectura Residencial em Mirobriga (Santiago do Cacém): contributo a partir de um estudo de caso Filipe Sousa / Catarina Felício

${ }_{1385}$ O fim do ciclo. Saneamento e gestão de resíduos nos edifícios termais de Mirobriga (Santiago do Cacém)

Catarina Felício / Filipe Sousa

1399 Balsa, Topografia e Urbanismo de uma Cidade Portuária Vítor Silva Dias / João Pedro Bernardes / Celso Candeias / Cristina Tété Garcia

1413 No Largo das Mouras Velhas em Faro (2017): novas evidências da necrópole norte de Ossonoba e da sua ocupação medieval Ricardo Costeira da Silva / Paulo Botelho / Fernando Santos / Liliana Nunes

1429 Instrumentos de pesca recuperados numa fábrica de salga em Ossonoba (Faro) Inês Rasteiro / Ricardo Costeira da Silva / Paulo Botelho

1439 A Necrópole Romana do Eirô, Duas Igrejas (Penafiel): intervenção arqueológica de 2016 Laura Sousa / Teresa Soeiro

1457 Ritual, descarte ou afetividade? A presença de Canis lupus familiaris na Necrópole Noroeste de Olisipo (Lisboa)

Beatriz Calapez Santos / Sofia Simões Pereira / Rodrigo Banha da Silva / Sílvia Casimiro / Cleia Detry / Francisca Alves Cardoso

1467 Dinâmicas económicas em Bracara na Antiguidade Tardia Diego Machado / Manuela Martins / Fernanda Magalhães / Natália Botica

1479 Cerâmicas e Vidros da Antiguidade Tardia do Edifício sob a Igreja do Bom Jesus (Vila Nova de Gaia) Joaquim Filipe Ramos

1493 Novos contributos para a topografia histórica de Mértola no período romano e na Antiguidade Tardia Virgílio Lopes

\section{8. Época Medieval}

1511 Cerâmicas islâmicas no Garb setentrional "português": algumas evidências e incógnitas Constança dos Santos / Helena Catarino / Susana Gómez / Maria José Gonçalves / Isabel Inácio / Gonçalo Lopes / Jacinta Bugalhão / Sandra Cavaco / Jaquelina Covaneiro / Isabel Cristina Fernandes / Ana Sofia Gomes 
1525 Contributo para o conhecimento da cosmética islâmica, em Silves, durante a Idade Média Rosa Varela Gomes

1537 Yábura e o seu território - uma análise histórico-arqueológica de Évora entre os séculos VIII-XII José Rui Santos

1547 A encosta sul do Castelo de Palmela - resultados preliminares da escavação arqueológica Luís Filipe Pereira / Michelle Teixeira Santos

1559 A igreja de São Lourenço (Mouraria, Lisboa): um conjunto de silos e de cerâmica medieval islâmica

Andreia Filipa Moreira Rodrigues

1571 O registo material de movimentações populacionais no Médio Tejo, durante os séculos XII-XIII. Dois casos de "sunken featured buildings", nos concelhos de Cartaxo e Torres Novas Marco Liberato / Helena Santos / Nuno Santos

1585 O nordeste transmontano nos alvores da Idade média. Notas para reflexão Ana Maria da Costa Oliveira

1601 Sepulturas escavadas na rocha do Norte de Portugal e do Vale do Douro: primeiros resultados do Projecto SER-NPVD

Mário Jorge Barroca / César Guedes / Andreia Arezes / Ana Maria Oliveira

1619 "Portucalem Castrum Novum" entre o Mediterrâneo e o Atlântico: o estudo dos materiais cerâmicos alto-medievais do arqueossítio da rua de D. Hugo, nํ. 5 (Porto) João Luís Veloso

1627 A Alta Idade Média na fronteira de Lafões: notas preliminares sobre a Arqueologia no Concelho de Vouzela

Manuel Luís Real / Catarina Tente

1641 Um conjunto cerâmico medieval fora de portas: um breve testemunho aveirense Susana Temudo

${ }_{1651}$ Os Lóios do Porto: uma perspetiva integrada no panorama funerário da Baixa Idade Média à Época Moderna em meios urbanos em Portugal

Ana Lema Seabra

1659 O Caminho Português Interior de Santiago como eixo viário na Idade Média Pedro Azevedo

1665 Morfologia Urbana: Um exercício em torno do Castelo de Ourém André Donas-Botto / Jaqueline Pereira

1677 Intervenção arqueológica na Rua Marquês de Pombal/Largo do Espírito Santo (Bucelas, Loures)

Florbela Estêvão / Nathalie Antunes-Ferreira / Dário Ramos Neves / Inês Lisboa

1691 O Cemitério Medieval do Poço do Borratém e a espacialidade funerária na cidade de Lisboa Inês Belém / Vanessa Filipe / Vasco Noronha Vieira / Sónia Ferro / Rodrigo Banha da Silva

1705 Um Espaço Funerário Conventual do séc. XV em Lisboa: o caso do Convento de São Domingos da Cidade Sérgio Pedroso / Sílvia Casimiro / Rodrigo Banha da Silva / Francisca Alves Cardoso

\section{9. Época Moderna e Contemporânea}

1721 Arqueologia Moderna em Portugal: algumas reflexões críticas em torno da quantificação de conjuntos cerâmicos e suas inferências históricas e antropológicas Rodrigo Banha da Silva / André Bargão / Sara da Cruz Ferreira

1733 Faianças de dois contextos entre os finais do século XVI e XVIII do Palácio dos Condes de Penafiel, Lisboa

Martim Lopes / Tomás Mesquita 
1747 Um perfil de consumo do século XVIII na foz do Tejo: O caso do Mercado da Ribeira, Lisboa Sara da Cruz Ferreira / Rodrigo Banha da Silva / André Bargão

1761 Os Cachimbos dos Séculos XVII e XVIII do Palácio Mesquitela e Convento dos Inglesinhos (Lisboa)

Inês Simão / Marina Pinto / João Pimenta / Sara da Cruz Ferreira / André Bargão / Rodrigo Banha da Silva

1775 "Tomar os fumos da erua que chamão em Portugal erua sancta». Estudo de Cachimbos provenientes da Rua do Terreiro do Trigo, Lisboa

Miguel Martins de Sousa / José Pedro Henriques / Vanessa Galiza Filipe

1787 Cachimbos de Barro Caulínitico da Sé da Cidade Velha (República de Cabo Verde)

Rodrigo Banha da Silva / João Pimenta / Clementino Amaro

1801 Algumas considerações sobre espólio não cerâmico recuperado no Largo de Jesus (Lisboa) Carlos Boavida

1815 Adereços de vidro, dos séculos XVI-XVIII, procedentes do antigo Convento de Santana de Lisboa (anéis, braceletes e contas)

Joana Gonçalves / Rosa Varela Gomes / Mário Varela Gomes

1837 Da ostentação, luxo e poder à simplicidade do uso quotidiano: arqueologia e simbologia de joias e adornos da Idade Moderna Portuguesa Jéssica Iglésias

1849 Os amuletos em Portugal - dos objetos às superstições: o coral vermelho Alexandra Vieira

1865 Cerâmicas de Vila Franca de Xira nos séculos XV e XVI Eva Pires

1879 «Não passa por teu o que me pertence». Marcas de individualização associadas a faianças do Convento de Nossa Senhora de Aracoeli, Alcácer do Sal Catarina Parreira / Íris Fragoso / Miguel Martins de Sousa

1891 Cerâmica de Leiria: alguns focos de produção

Jaqueline Pereira / André Donas-Botto

1901 Os Fornos na Rua da Biquinha, em Óbidos Hugo Silva / Filipe Oliveira

1909 A casa de Pêro Fernandes, contador dos contos de D. Manuel I: o sítio arqueológico da Silha do Alferes, Seixal (século XVI) Mariana Nunes Ferreira

1921 O Alto da Vigia (Sintra) e a vigilância e defesa da costa Alexandre Gonçalves / Sandra Santos

1937 O contexto da torre sineira da Igreja de Santa Maria de Loures Paulo Calaveira / Martim Lopes

1949 A Necrópole do Hospital Militar do Castelo de São Jorge e as práticas funerárias na Lisboa de Época Moderna Susana Henriques / Liliana Matias de Carvalho / Ana Amarante / Sofia N. Wasterlain

1963 SAND - Sarilhos Grandes Entre dois Mundos: o adro da Igreja e a Paleobiologia dos ossos humanos recuperados

Paula Alves Pereira / Roger Lee Jesus / Bruno M. Magalhães

1975 Expansão urbana da vila de Cascais no século XVII e XVIII: a intervenção arqueológica na Rua da Vitória no 15 a 17

Tiago Pereira / Vanessa Filipe

1987 Novos dados para o conhecimento do Urbanismo de Faro em época Moderna Ana Rosa 
1995 Um exemplo de Arqueologia Urbana em Alcoutim: o Antigo Edifício dos CTT Marco Fernandes / Marta Dias / Alexandra Gradim / Virgílio Lopes / Susana Gómez Martínez

2007 Palácio dos Ferrazes (Rua das Flores/Rua da Vitória, Porto): a cocheira de Domingos Oliveira Maia

Francisco Raimundo

2021 As muitas vidas de um edifício urbano: História, Arqueologia e Antropologia no antigo Recreatório Paroquial de Penafiel Helena Bernardo / Jorge Sampaio / Marta Borges

2035 O convento de Nossa Senhora da Esperança de Ponta Delgada: o contributo da arqueologia para o conhecimento de um monumento identitário João Gonçalves Araújo / N’Zinga Oliveira

2047 Arqueologia na ilha do Corvo... em busca da capela de Nossa Senhora do Rosário Tânia Manuel Casimiro / José Luís Neto / Luís Borges / Pedro Parreira

2059 Perdidos à vista da Costa. Trabalhos arqueológicos subaquáticos na Barra do Tejo Jorge Freire / José Bettencourt / Augusto Salgado

2071 Arqueologia marítima em Cabo Verde: enquadramento e primeiros resultados do projecto CONCHA

José Bettencourt / Adilson Dias / Carlos Lima / Christelle Chouzenoux / Cristóvão Fonseca / Dúnia Pereira / Gonçalo Lopes / Inês Coelho / Jaylson Monteiro / José Lima / Maria Eugénia Alves / Patrícia Carvalho / Tiago Silva

2085 Trabalhos arqueológicos na Cidade Velha (Ribeira Grande de Santiago, Cabo Verde): reflexões sobre um projecto de investigação e divulgação patrimonial André Teixeira / Jaylson Monteiro / Mariana Mateus / Nireide Tavares / Cristovão Fonseca / Gonçalo C. Lopes / Joana Bento Torres / Dúnia Pereira / André Bargão / Aurélie Mayer / Bruno Zélie / Carlos Lima / Christelle Chouzenoux / Inês Henriques / Inês Pinto Coelho / José Lima / Patrícia Carvalho / Tiago Silva

2103 A antiga fortificação de Quelba / Khor Kalba (E.A.U.). Resultados de quatro campanhas de escavações, problemáticas e perspectivas futuras Rui Carita / Rosa Varela Gomes / Mário Varela Gomes / Kamyar Kamyad

2123 Colónias para homens novos: arqueologia da colonização agrária fascista no noroeste ibérico Xurxo Ayán Vila / José Mạ . Señorán Martín 


\title{
IMAGENS FANTASMAGÓRICAS, SILHUETAS ELUSIVAS: AS FIGURAS HUMANAS NA ARTE DO PALEOLÍTICO SUPERIOR DA REGIÃO DO CÔA
}

\author{
Mário Reis ${ }^{1}$
}

\begin{abstract}
RESUMO
A representação da figura humana é rara na arte paleolítica europeia, e a região do Côa não é excepção, embora desde o início se conheçam antropomorfos paleolíticos na sua arte de ar livre. Inicialmente restringidos a dois sítios, a sua quantidade e dispersão territorial expandiu-se consideravelmente nos últimos anos, com os continuados trabalhos de prospecção, registo de rochas decoradas e revisão das já conhecidas, ascendendo actualmente a quase meia centena, pesem embora as dúvidas na classificação de várias entre elas. Este texto apresenta o conjunto completo destas figuras inventariadas na arte do Côa, dividindo-as nos seus principais grupos cronológicos e tipológicos, e reflectindo sucintamente sobre a sua possível continuação para a fase cultural subsequente ao Paleolítico Superior.
\end{abstract}

Palavras-chave: Arte rupestre, Figuras antropomórficas, Paleolítico Superior, Epipaleolítico, Região do Côa.

\begin{abstract}
The representation of the human figure is rare in European Paleolithic art, and the Côa region is no exception, although Paleolithic anthropomorphs have been known in its open-air art since the beginning. At first restricted to two sites, their quantity and territorial dispersion has considerably expanded in recent years, with the continued work of survey, review and registration of decorated rocks, and currently amount to almost half a hundred, despite the doubts concerning the classification of several among them. This text presents the complete set of these figures in the Côa art, divided in their main chronological and typological groups, and briefly reflecting on their possible continuation for the cultural phase subsequent to the Upper Paleolithic.

Keywords: Rock art, Anthropomorphic figures, Upper Paleolithic, Epipaleolithic, Côa Region.
\end{abstract}

\section{INTRODUÇÃO}

Apesar da sua raridade, as representações antropomórficas paleolíticas fazem parte do imaginário associado à arte do Côa, pois desde a revelação deste complexo de arte rupestre ao mundo em finais de 1994 que a existência de uma destas figuras foi desde logo conhecida e amplamente divulgada na comunicação social e nos meios científicos. Para mais, não se tratava de um motivo qualquer, e o "Homem de Piscos", como ficou designado na gíria, continua a ser uma das mais impressionantes figuras da arte paleolítica do Côa. A sua descoberta ocorreu em No- vembro de 1994 por intermédio dos técnicos ao serviço do "Projecto Arqueológico do Côa" (Rebanda, 1995, ficha 17), escassos dias antes do desencadear da imensa polémica científica e mediática do Côa. Durante anos manteve-se como a única figura do seu género dentro do imenso corpus figurativo da arte do Côa que ia sendo estudado e revelado. A partir de 1999, as fulcrais escavações arqueológicas no terraço fluvial do Fariseu permitiram o início da identificação de algumas raras figuras humanas na abundante arte móvel exumada neste sítio, algumas reveladas de imediato, outras aguardando por estudos mais detalhados do conjunto das peças, recentemente

1. Fundação Côa Parque / Centro de Estudos em Arqueologia, Artes e Ciências do Património da Universidade de Coimbra (CEAACP); marioreissoares@sapo.pt 
publicadas em pleno (Santos $\&$ alii, 2018). No mesmo sítio, o ano 2000 assiste à inventariação de várias novas rochas decoradas, com o estudo das rochas $4 \mathrm{e}$ 8 a permitir identificar novas figuras humanas, desde logo a partir de 2002 na rocha 8 , mas só mais tarde na rocha 4, com um palimpsesto de figuras incisas de dificílima decifração e onde só o levantamento completo em 2010 permitiu a identificação de duas novas figuras humanas. Antes disso, e num retorno ao vizinho sítio da Ribeira de Piscos, o ano de 1999 assistiu à descoberta da rocha 24 , que estava quase toda oculta por sedimentos e cuja escavação em 2000 e 2003 (Luís, 2009), permitiu o acesso a todos os seus muitos painéis decorados, permitindo a plena revelação de uma das mais extraordinárias rochas com arte rupestre do complexo do Côa, e também da sua abundante colecção de antropomorfos paleolíticos, cerca de uma vintena. Este era, aproximadamente, o quadro do conhecimento destas figuras na altura da sua primeira publicação conjunta em 2009, em que quase todas as figuras atrás mencionadas são referidas (Baptista, 2009, pp. 66, 90-107), faltando apenas as figuras da rocha 4 do Fariseu e algumas da arte móvel deste mesmo sítio.

Este quadro permitia uma constatação, que era a circunscrição das figuras humanas paleolíticas a uma zona restrita dentro do vale do Côa, definida pelos sítios vizinhos da Ribeira de Piscos e Fariseu. Essa restrição mantém-se válida para as figuras de um determinado tipo (o Tipo I, maioritariamente Magdalenense, e referido a seguir), as quais ainda hoje são conhecidas unicamente nesta área. Mas já não é válida para outros tipos de figuras, genericamente assignáveis aos momentos finais do Paleolítico Superior, numa fase que designarei neste trabalho como Tardiglaciar (abrangendo os dois ou três milénios correspondentes ao final do período glaciar e o princípio do Holoceno). Estas têm vindo paulatinamente a ser identificadas, em quantidades reduzidas mas numa ampla área territorial dentro do complexo do Côa, que se estende ao longo deste rio e avança para dentro do Douro. A sua identificação decorre desde logo dos trabalhos de prospecção de arte rupestre que tem decorrido continuadamente desde o início até aos dias de hoje, e dos consequentes trabalhos de estudo e registo das novas rochas que vão sendo descobertas, e da sempre importante revisão daquelas já conhecidas, que permite a actualização de conhecimentos e correcção de impressões iniciais, nem sempre acertadas, pela imensa dificul- dade em interpretar à vista desarmada a difícil arte do Côa. Para além da figura da rocha 17 da Penascosa, cedo identificada mas atribuída a cronologias mais recentes, e à qual só agora proponho uma cronologia paleolítica Tardiglaciar (ver abaixo), as restantes têm sido identificadas sobretudo por mim próprio desde 2005, ano em que a prospecção realizada na Foz do Côa permitiu a primeira referência, ainda hesitante, a figuras humanas paleolíticas externas ao referido duo de sítios (Baptista \& Reis, 2008, pp. 84-85). Algumas outras serão mencionadas de passagem em publicações posteriores de inventário geral da arte do Côa (Reis, 2012; 2013; 2014), e uma outra, no sítio do Vale Escuro, foi primeiramente atribuída ao Paleolítico Superior numa publicação recente (Santos $\&$ alii, 2018, pp. 59, 94), havendo ainda outras que se mantêm inéditas. Neste momento, entre figuras confirmadas, prováveis ou incertas, as representações humanas paleolíticas na região do Côa ascendem a quase meia centena, número que poderá futuramente subir com mais trabalhos de prospecção e estudo das rochas decoradas da região.

Neste trabalho apresento um inventário total das figuras humanas paleolíticas actualmente conhecido (Figura 1), com imagens da maioria (Figuras 2, 3 e 4). Todas foram executadas por gravação, exclusivamente pela técnica da incisão, com excepção das pouco evidentes figuras pintadas das peças 85 e 86 da arte móvel do Fariseu. Como se verá a seguir, podem separar-se em três tipos principais, e a sua cronologia divide-se entre o Magdalenense e o Tardiglaciar. Mas neste trabalho abordo também, de forma sumária, um outro conjunto de figuras, que chegam às três dezenas, integralmente realizadas por pintura e cujo inventário também está presente na Figura 1. São estilisticamente relacionáveis com um dos tipos principais das figuras paleolíticas, que abrange a maioria das figuras humanas Tardiglaciares, mas a sua cronologia e assignação cultural está ainda em aberto. Presentemente, coloco-as no Epipaleolítico, como parte da expressão artística comummente designada como arte Subnaturalista, de que são exemplos partes importantes da arte Levantina ou da arte do Tejo. No entanto, há questões que se levantam sobre a sua correcta classificação cultural e cronológica, que abordarei de forma muito sucinta no final deste texto, mas que são um dos temas principais da investigação sobre arte rupestre pré-histórica, neste momento e no futuro próximo, na região do Côa e na Península Ibérica. 
Contextualizando quantitativamente as 48 figuras humanas inventariadas no todo da arte paleolítica do Côa, distribuídas por apenas 15 registos (14 rochas mais a arte móvel do Fariseu) em nove dos 61 sítios (com 602 registos) com arte paleolítica, constata-se a sua raridade neste complexo, sendo apenas cerca de 1,1\% das figuras paleolíticas inventariadas (num universo superior a 4300), confirmando a norma europeia da escassez na representação deste tipo de figuras.

É importante referir que, questões cronológicas à parte, nem todas as figuras aqui inventariadas têm igual grau de confiança na sua classificação como representações humanas. A maioria das consideradas Magdalenenses têm um aspecto humano indubitável mas, do abundante conjunto da rocha 24 de Piscos, cinco levantam dúvidas na sua classificação: uma no painel 4 (Figura 2, no 8), duas no painel 7 (Figura 2, $\mathrm{n}^{\circ}{ }_{13}$ e 14), outra no painel 13 (Figura 2, ํำ16), e também a do painel 23. No Alto da Cotovia, uma das figuras da rocha 3 merece também algumas dúvidas (Figura 3, no 3 ), o mesmo acontecendo com a da rocha 1 da Vermelhosa embora, em ambos os casos, me pareça crível a sua classificação. Na rocha 148 da Foz do Côa, a semelhança estilística das figuras inventariadas com o universo das figuras "FFS" (ver a seguir) é indubitável, mas a falta de detalhes anatómicos explícitos permite dúvidas legítimas. $\mathrm{Na}$ arte móvel do Fariseu, as figuras das peças I (Baptista, 2009, p. 66; Santos \& alii, 2018, pp. 11, 83) e 4 (Baptista, 2009, p. 104; Santos $\&$ alii, 2018, pp. 14, 83) têm um aspecto humano claro, mas a da peça 48 (Santos \& alii, 2018, pp. 30-31, 89) não é evidente, com um conjunto de inúmeros traços com um formato apenas genericamente reconhecível como humano. É de classificação tipológica difícil, embora com mais parecenças com as do Tipo II, e poderia também tratar-se de um signo, ou de um conjunto de signos. Quanto às figuras pintadas das peças 85 e 86 (Santos \& alii, 2018, pp. 44-45, 93), têm um formato humano claro, mas o seu estado de conservação e extremo apagamento levanta algumas dúvidas quanto à sua identificação, e seria essencial o aparecimento de mais exemplares semelhantes que permitissem comparações fiáveis.

\section{REVISÃO DE ALGUMAS FIGURAS PUBLICADAS}

É importante apresentar uma revisão de um grupo de figuras relevantes para este texto. Três foram publicadas como antropomorfos paleolíticos, opinião que presentemente não partilho. Outra foi referida como pós-paleolítica, mas havendo agora razões para recuar essa cronologia aos momentos finais do Paleolítico Superior.

Dois exemplos surgem na rocha 1 do sítio da Vermelhosa, já sobre o Douro (Figura 4, nำ1). Nos primeiros trabalhos aqui realizados foi anunciada a possível existência de três figuras antropomórficas femininas paleolíticas, sendo apresentados esboços de duas delas (Abreu \& alii, 1998; Arcá, 1996). Este anúncio passou largamente despercebido, sendo referente a uma das rochas mais complexas da arte do Côa, com dezenas de figuras e milhares de traços, formando um dos densos palimpsestos presente em variadas rochas da região, de muito difícil apreciação. Ainda não desenhada, fiz um inventário da sua iconografia a partir de 2015, quando realizei um registo completo e com centenas de fotografias de todas as suas gravuras. Consegui identificar um dos motivos atrás mencionados, interpretado como uma figura feminina em perfil. Na realidade, não é um antropomorfo, sendo bastante maior do que o interpretado, prolongando-se acentuadamente para cima e para baixo, formando um longo meandro ondulado. Quanto à segunda figura, não consegui encontrar a sua correspondente no intrincado emaranhado de traços e motivos daquela superfície. Mas, à luz do conhecimento obtido sobre a arte paleolítica do Côa, não é difícil olhar para a imagem publicada e afirmar que não se trata de uma figura humana, nem mesmo híbrida, mas simplesmente uma representação zoomórfica, num estilo perfeitamente reconhecível nas representações animais da fase Tardiglaciar do Paleolítico Superior do Côa. Quanto à terceira figura, na falta de uma imagem publicada e de uma indicação precisa da sua localização na superfície, não foi possível a sua identificação, mas é improvável que se trate da possível e nova figura humana que eu próprio identifiquei nesta rocha, e que não tem nada que sugira ser feminina (ver Figura 3, no 12).

Outro caso de revisão classificativa ocorre com a única figura da rocha 18 da Quinta da Barca (Figura 4 , no 2). Feita num traço picotado largo, profundo e muito facilmente visível, foi sugerido que se tra- 
taria de uma figura híbrida paleolítica, de provável cronologia no período Gravetto/Solutrense (Baptista, 2009, p. 9o; Baptista, Santos \& Correia 2006). Uma opinião semelhante é reiterada recentemente, incluindo na cronologia, salientando o seu aspecto zoomórfico, mas referindo igualmente o seu possível lado humanoide (Santos, 2017, Vol. II, pp. 39-40). No entanto, creio que se pode colocar outra hipótese interpretativa, a nível tipológico e cronológico. Estilisticamente, tem semelhanças com representações zoomórficas da Pré-história pós-paleolítica, com vários exemplos na região do Côa. Com o corpo longo e estreito, patas e cabeça curtas, esta última com pequenos cornos, as maiores semelhanças são com a figura da rocha 3 da Canada do Inferno (Baptista \& Gomes, 1997, pp. 221-222, 268): representações zoomórficas pouco naturalistas, cuja identificação da espécie é difícil ou impossível, e numa semelhança que se estende às características do traço picotado, mais solto e disperso do que é a norma das figuras paleolíticas mais antigas. Reafirmando uma hipótese anteriormente expressa (Reis, 2012, pp. 34-35), a figura não é um híbrido paleolítico, mas sim um animal indeterminado da arte Subnaturalista do Epipaleolítico.

Por fim, a original figura da rocha 17 da Penascosa (Figura 3, no 5 ). De apreciáveis dimensões e com um grande falo erecto, colocada imediatamente por detrás de um animal paleolítico no que se encarou como uma possível cena de bestialismo encenada com uma figura muito mais antiga, foi cedo publicada como de cronologia pós-paleolítica, eventualmente neolítica, integrando-a no universo da Arte Esquemática (Baptista, 1999, pp. 112-113). Mesmo sem entrar em considerações estilísticas tão específicas, a sua atribuição a uma cronologia plenamente holocénica (no sentido cronológico e cultural) mantém-se em textos recentes (por exemplo, Santos, 2017, Vol. II, p. 93), e incluindo por mim próprio (Reis, 2012, p. 35), mas onde já relevo um aspecto importante: a semelhança estilística entre esta figura e alguns dos antropomorfos pintados da Faia.

Há algum tempo, no entanto, que revi a minha opinião sobre esta figura, tendo passado a incluí-la no universo cronológico do Tardiglaciar. Esta nova opinião baseia-se na comparação com várias novas descobertas na região do Côa, que referirei no capítulo 4, com a óbvia conclusão de que as características estilísticas deste conjunto de figuras são semelhantes, inseridas em contextos que apontam para os momentos finais do Paleolítico Superior. Baseia-se também na comparação com figuras conhecidas e datadas no exterior, de que o conhecido "Brujo" da Cueva Palomera de Ojo Guareña, em Burgos, Espanha, será o melhor exemplo (Corchón \& alii, 1996). E, finalmente, baseia-se na análise da figura no seu contexto imediato: a superfície onde foi gravada e as restantes figuras que a acompanham. A comparação relevante não é com a figura zoomórfica que lhe surge à frente e que inspirou a ideia da cena de bestialismo (a qual, embora possível, me parece improvável, sendo talvez apenas uma coincidência posicional). Pelo traço muito mais patinado e, sobretudo, pelo seu estilo muito cuidado e naturalista, é evidente que é uma figura muito mais antiga, seguramente Magdalenense, e que não pode ser emparelhada cronologicamente com esta. A comparação pode ser feita com outra figura que aparece imediatamente à direita da sua mão, e que passou despercebida porque no desenho que foi feito e posteriormente publicado (Santos, 2017, Vol. II, p. 94) não foi correctamente levantada: aparece como um mero feixe de traços mas, na realidade, é um pequeno cervídeo (ou caprino) estriado, cujo estilo remete indubitavelmente para o Paleolítico Tardiglaciar (ver Figura 4 , no 3 ). O aspecto relevante não está tanto na proximidade entre ambas as figuras, mas sim nas características do traço gravado. As linhas da gravura correspondem a uma espécie de "incisão raspada", muito diferente do traço da figura Magdalenense, mas comum ao caprino e ao antropomorfo, e aparecendo em outros conjuntos de traços na rocha. A semelhança sugere a sua contemporaneidade, talvez até a mesma autoria e, juntando com as outras comparações acima referidas, sugere com clareza a pertença da figura humana aos momentos finais do Paleolítico Superior. É bem possível que seja já holocénica, dado que o Tardiglaciar se prolonga para tempos pós-glaciares, mas a sua pertença cultural vincula-se ainda ao Paleolítico Superior.

\section{A FIGURA HUMANA NO MAGDALENENSE: RIBEIRA DE PISCOS E FARISEU}

As primeiras figuras humanas paleolíticas claramente identificadas na região (Baptista, 2009, pp. 90-107), para além de se circunscreverem a apenas dois sítios numa zona muito restrita do Côa, formam um conjunto estilisticamente bastante homogéneo, do qual não parece haver grandes dúvidas na sua atri- 
buição cronológica e cultural ao Magdalenense, seja por comparações com outras figuras europeias, seja pela sua contextualização local, nomeadamente nas próprias rochas onde surgem. É certo que em duas das quatro rochas onde estas figuras foram identificadas aparecem pontualmente algumas (raras) figuras da fase Tardiglaciar do Paleolítico Superior, mas parecendo assegurada a sua ausência das rochas 2 da Ribeira de Piscos e 4 do Fariseu. Ou seja, estes motivos mais tardios não fornecem uma apta contextualização às figuras humanas das quatro rochas. Pelo contrário, todas as quatro, sem excepção, apresentam em abundância um conjunto variado de figuras de clara cronologia Magdalenense, caracterizada pelo elevado naturalismo e detalhe das figuras zoomórficas, muitas das quais se associam, de forma mais ou menos directa, a algumas das figuras antropomórficas, como na rocha 8 do Fariseu ou nalguns casos da rocha 24 de Piscos.

Quanto à distribuição, o Fariseu congrega apenas três figuras: uma na rocha 8 , bem evidente e colocada por cima de um caprino (Baptista, 2009, pp. 106-107; Santos, 2017, Vol. II, p. 196). Na rocha 4 as duas figuras são menos evidentes, mas a análise do desenho indica bem a sua existência (Santos, 2017, Vol. II, p. 191). Na Ribeira de Piscos, a rocha 24 tem 2o figuras antropomórficas, uma extraordinária coleção no mundo da arte paleolítica e que faz juz à que é, em todos os aspectos, uma extraordinária rocha decorada (ver Santos, 2017, Vol. II, pp. 121-168). E claro está, é na rocha 2 que se encontra o famoso Homem de Piscos (Baptista, 1999, pp. 122-123, 126-127), que congrega em si o ser a primeira figura humana identificada na arte rupestre da região (paleolítica e não só) e, dentro do conjunto das de cronologia paleolítica, ser também a de maior dimensão (cerca de $50 \mathrm{~cm}$ de altura) e a mais expressiva, com uma clara simbologia de cariz sexual, curiosamente semelhante à da figura da Penascosa.

\section{A EXPANSÃO DO TARDIGLACIAR. DO CÔA AO DOURO}

As novas figuras antropomórficas identificadas nos últimos anos juntam várias características distintas do grupo anterior: são todas mais recentes (com dúvidas pontuais numa ou outra situação), têm uma distribuição na região muito ampla e dispersa, são tipologicamente diferentes das figuras do grupo Piscos/Fariseu, mas também apresentam maior diversidade, dividindo-se em dois grandes tipos: um corresponde às conhecidas silhuetas femininas designadas habitualmente por "FFS" (Figures Féminines Schématiques) ou figuras femininas "tipo Gönnersdorf”, e é reduzido, estando limitado a uma única figura na peça 1 da arte móvel do Fariseu e a um conjunto de pelo menos sete figuras na rocha 148 da Foz do Côa. Todas as restantes, em número de quinze, pertencem a um mesmo tipo, pesem embora algumas dúvidas na caracterização tipológica de uma ou outra, e distribuem-se por 9 rochas em sete sítios (Alto da Cotovia, Penascosa, Broeira, Foz do Côa, Vale de José Esteves, Vermelhosa e Vale Escuro) e por algumas das peças da arte móvel do Fariseu, embora estes últimos casos sejam precisamente dos que levantam dúvidas tipológicas. Para além destas últimas e do exemplar da rocha 17 da Penascosa, quase todas são inéditas, exceptuando a figura da rocha 11 do Vale Escuro (Santos $\mathbb{\&}$ alii, 2018, pp. 59, 94). A sua distribuição é vasta, começando no importante sítio do Alto da Cotovia, a mais de 30 quilómetros de distância da foz do Côa, seguindo-se a Penascosa, a uma dezena de quilómetros deste ponto geográfico, do qual já se aproximam os restantes exemplares, na rocha 11 da Broeira e nas rochas 151 e 170 da Foz do Côa (ainda no Côa), ou nas rochas 4 do Vale de José Esteves, 1 da Vermelhosa e 11 do Vale Escuro, sobre o Douro.

A sua contextualização cronológica por associação a outras figuras tipicamente Tardiglaciares é semelhante à das figuras Magdalenenses do Tipo I, estando presente em quase todas as rochas em que surgem a estas figuras. Para além do caso já analisado da rocha 17 da Penascosa, existe uma associação a figuras zoomórficas Tardiglaciares também na rocha 11 do Vale Escuro, e uma associação particularmente forte e evidente nas rochas 151 da Foz do Côa e 1 da Vermelhosa. Também na rocha 170 da Foz do Côa essa contextualização é evidente, por razões que serão detalhadas mais abaixo, enquanto que no Alto da Cotovia a contextualização pode ser estendida a todo o conjunto das rochas paleolíticas do sítio, muito homogéneas do ponto de vista estilístico e onde também pontuam figuras zoomórficas estriadas Tardiglaciares. Menos evidente é o caso da rocha 11 da Broeira, cujos dois antropomorfos se associam apenas a signos, e estando a rocha imediatamente por cima da rocha 1, com motivos tanto Magdalenenses como Tardiglaciares. Também pouco clara é a associação do antropomorfo da rocha 4 do Vale 
de José Esteves, num sítio onde os motivos Tardiglaciares são extraordinariamente abundantes e dominantes, mas sendo a rocha 4 precisamente uma excepção, com raros motivos Tardiglaciares e enorme abundância de figuras Magdalenenses. As três figuras da arte móvel do Fariseu (peças 48, 85 e 86) têm uma contextualização cronológica evidente, mas são das mais atípicas dentro do Tipo II. Uma situação menos evidente ocorre na contextualização das figuras da rocha 148 da Foz do Côa. Desde logo, e aceitando a sua inclusão no Tipo III das "FFS", estas têm uma larga diacronia na arte Paleolítica Europeia (cf. Bosinski, 2011), pela que a sua classificação cronológica por comparação estilística é difícil. A rocha 148 apresenta numerosas outras figuras paleolíticas, todas Tardiglaciares, mas a zona do sítio onde se insere é precisamente onde aparece a maior concentração de rochas com figuras Magdalenenses, algumas bem perto desta, pelo que, também por aqui, contextualizar localmente estas figuras seja tarefa árdua. Parece-me, tendo em conta a realidade da arte do Côa, que uma cronologia Tardiglaciar é a mais provável, pela imensa abundância das figuras desta fase face às anteriores, mas é uma questão que se mantém aberta.

\section{OS TRÊS PRINCIPAIS TIPOS DE FIGURAS HUMANAS PRESENTES NA REGIÃO DO CÔA}

Olhando para o quadro das figuras humanas actualmente inventariadas no Côa, é possível fazer uma separação em três grandes tipos: o Tipo I é o das figuras humanoides, frequentemente grotescas mas de laivos naturalistas, com ampla variedade e usualmente datáveis do Magdalenense; o Tipo II é das figuras estilizadas e estereotipadas do Tardiglaciar; o Tipo III, mais raro, é o das figuras femininas de perfil.

O Tipo I está circunscrito a dois sítios vizinhos no Côa, a Ribeira de Piscos e o Fariseu, sendo composto por 25 exemplares (Figura 2). É o tipo de figura mais abundante, mas presente em apenas quatro rochas, duas em cada um dos sítios, e ainda na peça 4 da arte móvel do Fariseu. Tipologicamente, definem-se sucintamente como figuras de representação subnaturalista e não estereotipada, em que o desenho da forma humana assume algum realismo e proporcionalidade, com as silhuetas da cabeça, corpos e membros a serem facilmente reconhecíveis, por vezes com detalhes anatómicos (olhos, orelhas, se- xos,...), em alguns casos raros até com peças de roupa reconhecíveis. No entanto, não se podem considerar como representações naturalistas de seres humanos, e uma das suas características essenciais e unificadoras é o seu aspecto tendencialmente grotesco, por vezes animalesco ou mesmo deformado. No Côa, o Homem de Piscos é talvez a mais naturalista de todas as figuras humanas da região, mas a sua expressão é grotesca e as proporções corporais têm notórias incorrecções; uma ou outra das figuras da rocha 24 da Ribeira de Piscos entram no que se pode considerar o domínio do fantástico ou monstruoso, enquanto que outras não passam de silhuetas mal reconhecíveis como seres humanos ou até reduzidas a uma forma circular que se presume corresponder a uma cabeça, como nos painéis 4 e 13. Assim, dentro de um ar de família reconhecível, a variedade e a não conformação estereotípica é outro dos principais aspectos deste tipo específico de figuras, a que se junta a sua forte expressividade cénica. Há muitas figuras humanas europeias associáveis a este tipo, entre as quais o homem da cena do Poço de Lascaux; o chamado feiticeiro da gruta de Saint-Cirq; as figuras humanas da gruta de Le Portel ou, num dos casos que mais evoca as figuras do Côa, a figura híbrida da gruta de Hornos de La Peña (ver, por exemplo, Clottes, 2008, pp. 120-121, 136-137, 171, 216). Também as abundantes figuras da arte móvel de La Marche se poderão integrar neste tipo, neste caso com exemplares naturalistas, até mesmo retratistas, da fisionomia humana (Pales \& Saint Péreuse, 1976). O Homem de Piscos, na sua cena sexual onanista, é a maior e mais conhecida figura humana paleolítica da arte do Côa, notavelmente expressiva, nomeadamente na expressão facial grotesca, e anatomicamente muito detalhada, sobretudo na cabeça e na representação do falo. A rocha 24 da Ribeira de Piscos apresenta outras figuras, com grande variedade de detalhes e contextos "cénicos". Por exemplo, o par de figuras dos painéis $2 \mathrm{e} 3$, uma feminina e outra masculina colocadas quase lado a lado, numa localização talvez intencional, ambas com aparente representação de vestimentas (que poderá eventualmente aparecer também numa das figuras da rocha 4 do Fariseu), e que olham de frente para o observador. Também a olhar de frente estão as peculiares figuras do painel 4 que se "abraçam fraternalmente" pelos ombros. Plenamente de perfil encontra-se uma figura do painel 7, de forma plenamente humana e em movimento dinâmico, de perna e braço 
avançado, e com uma cabeça de formato dilatado e quase animalesco. De muito difícil percepção mas absolutamente notável é uma possível representação de uma mulher grávida no painel 17, segurando a barriga dilatada com as mãos, infelizmente sem a cabeça, perdida por fracturação. Evocando o mundo fantástico ou monstruoso estão a figura do painel 5 , de forma humanoide simples e de cuja face emerge um auroque, numa extraordinária composição, ou a muito estranha figura do painel 6 , intencionalmente sem cabeça e mesclando o humano com o grotesco e monstruoso, e que aparenta estar relacionada com duas figuras animais anexas, sobreposta a um auroque de forma que sugere o acto de "cavalgar", e com o braço estendido de forma a que a mão parece segurar um pequeno caprino. A evocação do acto de cavalgar surge de novo na figura da rocha 8 do Fariseu, com uma figura de forma humana simples mas colocada sobre o dorso de um caprino (na Figura 2, no 24 , o desenho desta figura foi feito por mim a partir de fotografia e tem pequenas diferenças face ao publicado, onde a figura animal sugere um misto de cavalo e caprino).

Uma última figura a merecer menção encontra-se na peça 4 da arte móvel do Fariseu, tipologicamente apartada dos restantes antropomorfos neste conjunto. Representa um antropomorfo visto de frente, com a cabeça redonda e a parte superior do corpo, tendo-se o resto perdido por fracturação, e tendo também impactos de picotagem no interior da face, assim como um conjunto de traços que emanam da cabeça para o exterior. Desde logo, esta figura chama a atenção pela questão cronológica. Todas as outras figuras humanas incluídas no Tipo I podem ser colocadas no Magdalenense, pelas razões atrás mencionadas. Mas esta peça foi encontrada na U.E. 4 da escavação do Fariseu, bem datada do Tardiglaciar (cf. Aubry \& Sampaio, 2008), pelo que surge num contexto bastante posterior. No entanto, estilisticamente, é claramente comparável com as figuras Magdalenenses do Tipo I. Essa comparação advém da forma do corpo, de formas humanóides redondeadas. Mas, sobretudo, prende-se com o conjunto de traços que emanam para fora da cabeça. De sentido muito obscuro, uma vez que não parece tratar-se de representação de cabelo, este tracejamento surge em quatro outras figuras Magdalenenses, todas na Ribeira de Piscos, com o Homem de Piscos na rocha 2 e mais três figuras na rocha 24, incluindo o par masculino/ feminino atrás mencionado, e a sua presença nalgu- mas das mais notáveis figuras antropomórficas da região torna-o um detalhe estilístico muito relevante e, na ausência de dados em contrário, como um "fóssil director" do Tipo I dentro da região do Côa (pelo menos). A discrepância cronológica desta figura face às restantes poderá talvez ser explicada por duas hipóteses: em primeiro lugar, uma sobrevivência para dentro do Tardiglaciar de uma característica estilística própria do Magdalenense; ou, em alternativa, uma origem Magdalenense daquela peça em particular, e a sua sobrevivência "funcional" até ao seu descarte no Tardiglaciar.

O Tipo II é representado por 15 figuras, na região do Côa. São assinalavelmente distintas das figuras do Tipo I e muito mais uniformes e estereotipadas (Figura 3, no 1 a 13). Caracterizam-se por um formato corporal longo e esguio, os membros também longos e estreitos, com frequente desproporcionalidade. $\mathrm{O}$ uso do traço estriado é comum a todas as figuras da região. Os detalhes anatómicos são poucos, quase sempre toscamente desenhados. A representação fálica é frequente, e não há figuras com características femininas. As cabeças são geralmente pouco esboçadas, por vezes inexistentes, raramente assumindo uma forma arredondada. Os membros só por vezes são rematados por pés ou mãos, destacando-se estas últimas, geralmente com enormes dedos. Assim, em termos gerais, caracterizam-se como figuras estriadas, pouco naturalistas, pouco variadas, predominando um formato grandemente estereotipado, com escassa expressividade. A comparação mais evidente dentro da arte paleolítica europeia é com o já mencionado "Brujo" da Cueva Palomera de Ojo Guareña, num tipo de figuras particularmente relevante em contexto ibérico.

Olhando para os exemplares representados na Figura 3, é fácil compreender a inclusão da figura da rocha 17 da Penascosa neste conjunto. Tem alguma originalidade própria, nomeadamente por parecer repetir a cena de onanismo presente na bem mais antiga figura da rocha 2 da Ribeira de Piscos. A figura da rocha 170 da Foz do Côa merece uma menção especial. É o motivo central de um alinhamento de três, em que os dois laterais correspondem a peixes, de corpo oval estriado, e tendo uma clara cronologia Tardiglaciar. A figura central tem também longo corpo oval estriado, assim como dois longos apêndices inferiores interpretáveis como a cauda, semelhantes às das figuras laterais. No entanto, seja como acrescento posterior seja como composição de raiz, a figu- 
ra apresenta igualmente dois pés, um possível braço e, sobretudo, uma cabeça redonda, que lhe confere um aspecto indubitavelmente humano, sem perder a conexão, seguramente de simbolismo importante, com as figuras de peixe, podendo assim ser considerada uma figura híbrida. Quanto ao sítio do Alto da Cotovia, assume grande importância no tocante às figuras antropomórficas: no denso aglomerado de cinco rochas paleolíticas inventariadas neste sítio, duas apresentam figuras humanas, e outras duas têm alguns motivos indeterminados que, pelo formato, poderiam ser também antropomorfos, embora lhes faltem detalhes anatómicos mais explícitos.

O Tipo III é representado por oito figuras: uma na peça 1 da arte móvel do Fariseu, e sete num notável conjunto da rocha 148 da Foz do Côa (Figura 3, nº 14 e 15). Integram um tipo de figuras bem conhecido da arte paleolítica europeia, o das figuras femininas em perfil, um grupo muito específico dentro da representação humana paleolítica (ver Bosinski, 2011). A imagem de marca destas figuras é a sua silhueta em perfil com acentuada curvatura nas nádegas, conferindo-lhes uma tipologia inconfundível, independentemente da existência de outros detalhes anatómicos humanos. A figura da peça 1, de minúsculas dimensões, não é das mais típicas, mas apresenta a conhecida silhueta em perfil com a exagerada curvatura da nádega. O mesmo sucede nas figuras da rocha 148 da Foz do Côa, que se apresentam em sequência ordenada por baixo e ao longo de uma linha em semicírculo emergindo de um caos de linhas à esquerda para um alinhamento de sete figuras individualizadas, que recordam as possíveis danças que surgem como interpretação para alguns conjuntos semelhantes na Europa paleolítica, sendo relativamente frequentes os grupos de figuras em alinhamentos (cf. Bosinski 2011). Na falta de detalhes anatómicos mais explícitos nomeadamente braços ou seios, é importante recordar que se mantém a possibilidade de serem simplesmente um grupo de meandros, mas a hipótese antropomórfica continua a parecer-me a mais provável.

\section{CONCEPTUALIDADES: O TARDIGLACIAR E O EPIPALEOLÍTICO NA REPRESENTAÇÃO HUMANA}

Apesar do seu estatuto ultraminoritário no conjunto das figuras paleolíticas da região do Côa, é clara a importância simbólica da representação humana, assim como a sua mais longa diacronia face ao conhecido inicialmente. Mas, para finalizar este texto, falta conectar as figuras gravadas, bem inseridas dentro de um contexto paleolítico, com as figuras pintadas, cuja contextualização é, actualmente, menos evidente do que se pensava. Há um ar de família estilístico muito forte entre um grupo particular de representações antropomórficas pintadas na região do Côa, com as mais conhecidas a situarem-se no sítio da Faia, a que se juntam outros exemplares mais recentemente identificados no sítio do Ervideiro (ver Figura $4, n^{\circ} 7$ ). Num estado de conservação deplorável, é menos certo que se possam juntar a este conjunto duas figuras do abrigo da Ribeirinha, cuja inclusão neste inventário é, para já, hipotética. Também incerta é a inclusão do conhecido antropomorfo de mãos ao alto da rocha 1 da Faia (Baptista, 1999, p. 16o), embora me pareça provável, até pelo seu afastamento dos cânones mais típicos da Arte Esquemática. As restantes figuras seguem, com algumas variantes, um esquema semelhante: corpo alto e esguio, por vezes inclinado, cabeças apenas esboçadas e pouco detalhadas, por vezes inexistentes, membros longos, por vezes com o nítido desenho das mãos. Ou seja, são figuras estilisticamente semelhantes às do Tipo II, com a diferença de que são pintadas, e tendencialmente maiores. Um exemplo típico é a grande figura da rocha 3 da Faia (Baptista, 1999, p. 158), similar às duas figuras da rocha 5 do mesmo sítio. E, como já foi referido, são também semelhantes à figura pintada da peça 85 do Fariseu (cf. Santos \& alii, 2018, p. 56). E esta semelhança levanta naturalmente algumas questões. Deve-se incluir este conjunto de figuras dentro da arte paleolítica, nos seus momentos Tardiglaciares? Se sim, deve juntar-se-lhes as figuras zoomórficas que lhes são normalmente associadas dentro do estilo subnaturalista, de que no Côa os exemplos mais conhecidos são o veado picotado da rocha 1 de Vale de Cabrões e os bovinos pintados da rocha 1 da Faia (Baptista, 1999, pp. 138-139, 159)? Ou, em alternativa, deve-se assumir o parentesco estilístico destas figuras, humanas e animais, com as da fase final do Paleolítico Superior (o que parece, de uma ou outra forma, ser uma evidência actual), mas considerá-las como pertencentes a uma posterior fase cultural, normalmente denominada por Epipaleolítico? Estas questões, de resposta complexa, são hoje candentes na investigação da arte rupestre pré-histórica europeia e peninsular, também importantes nos conjuntos 
artísticos do Tejo português e do Levante espanhol, entre outros. Serão também um dos objectivos primordiais da investigação recentemente iniciada, no âmbito do projecto "LandCRAFT - os contextos socio-culturais da arte da Pré-história Recente no vale do Côa", que se espera venha trazer nova informação a este assunto (Alves, 202O).

\section{BIBLIOGRAFIA}

ABREU, Mila Simões; ARCÀ, Andrea; FOSSATI, Angelo; JAFFE, Ludwig (1998) - Palaeolithic rock engravings at Vermelhosa, Côa Valley Archaeological Park, Portugal. In CREMONESI, Renata Griffoni; TOZZI, Carlo; VIGLIARDI, Alda; PERETTO, Carlo, eds., - Proceedings of the XIII International Congress of Prehistoric and Protohistoric Sciences Vol. 3. Forli: A.B.A.C.O. Edizioni, pp. 121-125.

ALVES, Lara Bacelar (2020) - LandCRAFT. A arte da Pré-história Recente no vale do Côa. Kairós. Coimbra. 5, pp. 6-21.

AUBRY, Thierry; SAMPAIO, Jorge Davide (2008) - Chronologie et contexte archéologique des gravures paléolithiques de plein air de la Vallée du Côa (Portugal). In BEHRMANN, Rodrigo de Balbín, ed., - Arte Prehistorico al aire libre en el Sur de Europa. Salamanca: Junta de Castilla y Léon, pp. 211-223.

ARCÀ, Andrea (1996) - Palaeolithic figures in rock n. 1 of the Vermelhosa-Côa Valley area. Tracce Online Rock ArtBulletin. Valcamonica. 5. http://www.rupestre.net/tracce/?p=1033.

BAPTISTA, António Martinho (1999) - No tempo sem tempo: A arte dos caçadores paleolíticos do Vale do Côa. Com uma perspectiva dos ciclos rupestres pós-glaciares. Vila Nova de Foz Côa: Parque Arqueológico do Vale do Côa/Centro Nacional de Arte Rupestre.

BAPTISTA, António Martinho (2009) - O paradigma perdido. O Vale do Côa e a Arte Paleolítica de ar livre em Portugal. Vila Nova de Foz Côa: Edições Afrontamento / Parque Arqueológico do Vale do Côa.

BAPTISTA, António Martinho; GOMES, Mário Varela (1997) - Arte Rupestre. In ZILHÃO, João, ed., - Arte rupestre e pré-história do Vale do Côa. Trabalhos de 1995-1996. Lisboa: Ministério da Cultura, p. 213-406.

BAPTISTA, António Martinho; REIS, Mário (2008) - Prospecção da Arte Rupestre na Foz do Côa. Da iconografia do Paleolítico superior à do nosso tempo, com passagem pela II I Idade do Ferro. In Actas do III Congresso de Arqueologia de Trás-os-Montes, Alto Douro e Beira Interior. Vol. o1 - Pré-história. Gestos Intemporais. Vila Nova de Foz Côa: Associação Cultural Desportiva e Recreativa de Freixo de Numão, pp. 62-95.

BAPTISTA, António Martinho; SANTOS, André Tomás; CORREIA, Dalila (2006) - Da ambiguidade das margens na Grande Arte de ar livre no Vale do Côa. Reflexões em torno da organização espacial do santuário Gravetto-Solutrense na estação da Penascosa / Quinta da Barca. Côavisão. Vila Nova de Foz Côa. 8, pp. 156-184.

BOSINSKI, Gerhard (2011) - Femmes sans tête. Une icône culturelle dans l'Europe de la fin de l'époque glaciaire. Paris: Éditions Errance.

CLOTTES, Jean (2008) - Cave Art. New York: Phaidon.

CORCHÓN, Maria Soledad; VALLADAS, Hélène; BÉCARES, Julián; ARNOLD, Maurice; TISNERAT, Nadine; CACHIER, Hélène (1996) - Datación de las pinturas y revision del arte paleolítico de Cueva Palomera (Ojo Guareña, Burgos, España). Zephyrus. Salamanca. 49, pp. 37-6o.

LUís, Luís (2009) - A rocha 24 da Ribeira de Piscos: contexto estratigráfico de uma rocha gravada. In AUBRY, Thierry, ed., - 200 séculos da história do Vale do Côa: Incursões na vida quotidiana dos caçadores artistas do Paleolítico. Lisboa: Instituto de Gestão do Património Arquitectónico e Arqueológico, pp. 84-93.

PALES, León; SAINT PÉREUSE, Marie Tassin (1976) -Les Gravures de La Marche. II.-Les Humains. Bordeaux: Ophrys.

REBANDA, Nelson (1995) - Barragem de Vila Nova de Foz-Côa. Breve balanço dos trabalhos arqueológicos. Relatório policopiado, Lisboa: Instituto Português do Património Arquitectónico e Arqueológico (Processo 9o/1(374), Arquivo da Arqueologia Portuguesa, Direcção-Geral do Património Cultural).

REIS, Mário (2012) - 'Mil rochas e tal...'? Inventário dos sítios da arte rupestre do vale do Côa. Portvgalia. Porto. 33, pp. 5-72.

REIS, Mário (2013) - 'Mil rochas e tal...!': Inventário dos sítios da arte rupestre do vale do Côa ( $2^{\mathrm{a}}$ parte). Portvgalia. Porto. 34, pp. 5-68.

REIS, Mário (2014) - 'Mil rochas e tal...'?': Inventário dos sítios da arte rupestre do vale do Côa (Conclusão). Portvgalia. Porto. 35, pp. 17-59.

SANTOS, André Tomás Pinto da Silva e Conceição (2017) - A arte paleolítica ao ar livre da bacia do Douro à margem direita do Tejo: uma visão de conjunto. Tese de Doutoramento policopiada. Porto: Universidade Porto.

SANTOS, André Tomás; AUBRY, Thierry; BARBOSA, A. F.; GARCÍA DIEZ, Marcos; SAMPAIO, Jorge Davide (2018) - O final do ciclo gráfico paleolítico do Vale do Côa: A arte móvel do Fariseu (Muxagata, Vila Nova Foz Côa). Portvgalia. Porto. 39, pp. 5-96. 


\begin{tabular}{|c|c|c|c|c|c|c|c|c|c|}
\hline \multirow[t]{2}{*}{ Registo } & \multicolumn{3}{|c|}{ Magdalenense } & \multicolumn{3}{|c|}{ Tardiglaciar } & \multicolumn{3}{|c|}{ Epipaleolítico } \\
\hline & I & II & III & I & II & III & I & II & III \\
\hline R. Piscos 2 & 1 & - & - & - & - & - & - & - & - \\
\hline R. Piscos 24 (2) & 1 & - & - & - & - & - & - & - & - \\
\hline R. Piscos 24 (3) & 3 & - & - & - & - & - & - & - & - \\
\hline R. Piscos 24 (4) & 3 & - & - & - & - & - & - & - & - \\
\hline R. Piscos 24 (5) & 1 & - & - & - & - & - & - & - & - \\
\hline R. Piscos 24 (6) & 1 & - & - & - & - & - & - & - & - \\
\hline R. Piscos 24 (7) & 4 & - & - & - & - & - & - & - & - \\
\hline R. Piscos 24 (12) & 1 & - & - & - & - & - & - & - & - \\
\hline R. Piscos 24 (13) & 2 & - & - & - & - & - & - & - & - \\
\hline R. Piscos 24 (17) & 1 & - & - & - & - & - & - & - & - \\
\hline R. Piscos $24(21)$ & 1 & - & - & - & - & - & - & - & - \\
\hline R. Piscos 24 (23) & 1 & - & - & - & - & - & - & - & - \\
\hline R. Piscos 24 (28) & 1 & - & - & - & - & - & - & - & - \\
\hline Fariseu a. m. (1) & - & - & - & - & - & 1 & - & - & - \\
\hline Fariseu a. m. (4) & - & - & - & 1 & - & - & - & - & - \\
\hline Fariseu a. m. (48) & - & - & - & - & 1 & - & - & - & - \\
\hline Fariseu a. m. (85) & - & - & - & - & 1 & - & - & - & - \\
\hline Fariseu a. m. (86) & - & - & - & - & 1 & - & - & - & - \\
\hline Fariseu 4 & 2 & - & - & - & - & - & - & - & - \\
\hline Fariseu 8 & 1 & - & - & - & - & - & - & - & - \\
\hline Foz do Côa 148 & - & - & - & - & - & 7 & - & - & - \\
\hline Foz do Côa 151 & - & - & - & - & 1 & - & - & - & - \\
\hline Foz do Côa 170 & - & - & - & - & 1 & - & - & - & - \\
\hline V. J. Esteves 4 & - & - & - & - & 1 & - & - & - & - \\
\hline Penascosa 17 & - & - & - & - & 1 & - & - & - & - \\
\hline Vermelhosa 1 & - & - & - & - & 1 & - & - & - & - \\
\hline Broeira 11 & - & - & - & - & 2 & - & - & - & - \\
\hline Vale Escuro 11 & - & - & - & - & 1 & - & - & - & - \\
\hline Alto da Cotovia 2 & - & - & - & - & 2 & - & - & - & - \\
\hline Alto da Cotovia 3 & - & - & - & - & 2 & - & - & - & - \\
\hline Faia 1 & - & - & - & - & - & - & - & 1 & - \\
\hline Faia 3 & - & - & - & - & - & - & - & 1 & - \\
\hline Faia 5 & - & - & - & - & - & - & - & 2 & - \\
\hline Faia 8 & - & - & - & - & - & - & - & 7 & - \\
\hline Ervideiro 1 & - & - & - & - & - & - & - & 5 & - \\
\hline Ervideiro 2 & - & - & - & - & - & - & - & 12 & - \\
\hline Ribeirinha 1 & - & - & - & - & - & - & - & 2 & - \\
\hline TOTAL & 24 & - & - & 1 & 15 & 8 & - & 30 & - \\
\hline
\end{tabular}

Figura 1 - Relação das figuras antropomórficas de cronologia Paleolítica e Epipaleolítica da região do Côa, indicando-se os sítios e registos de origem e o tipo em que se inserem. Na arte móvel do Fariseu indica-se a número da peça, e na rocha 24 da Ribeira de Piscos indica-se o número do painel. 


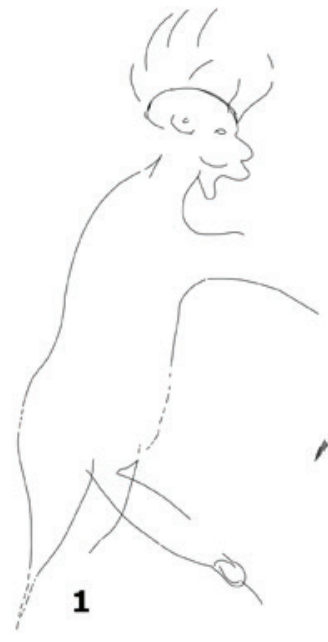

Tipo I
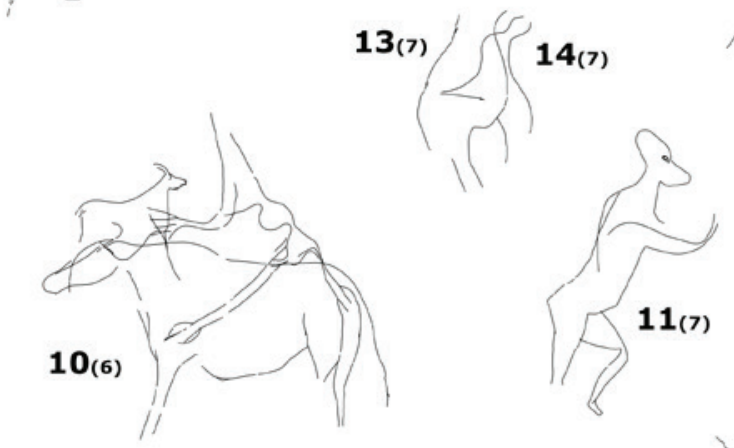

$4(3)$

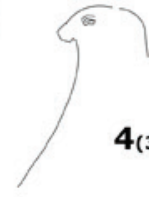

$5(3)$
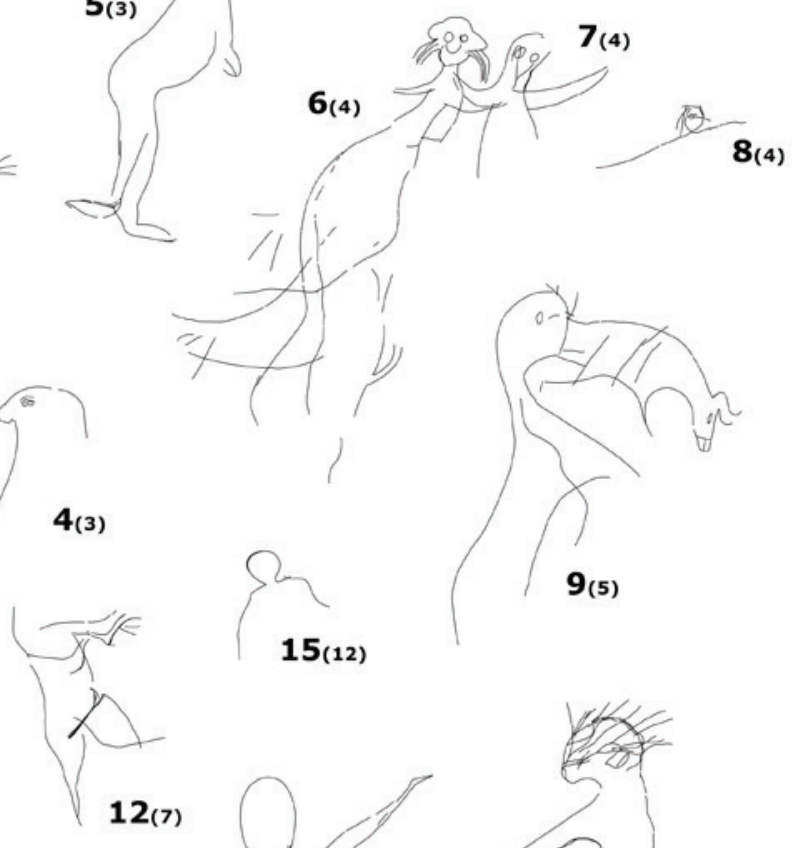<smiles></smiles>
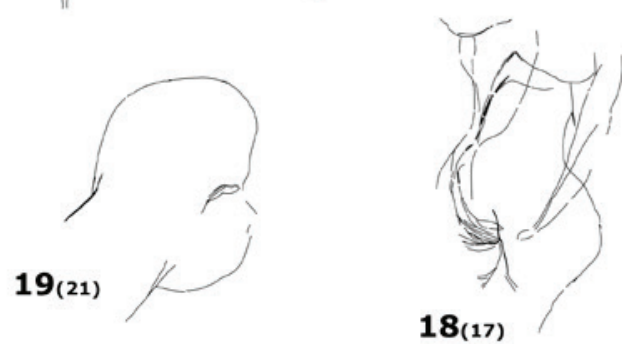

17(13)

$16(13)$

15(12)

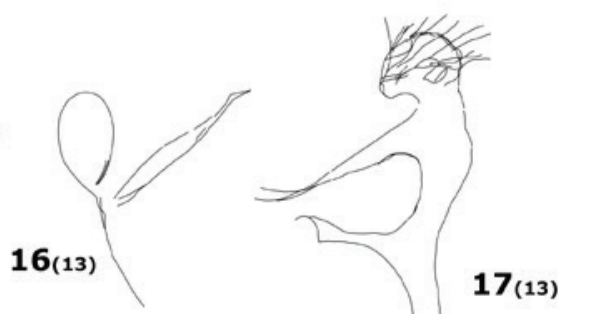

22
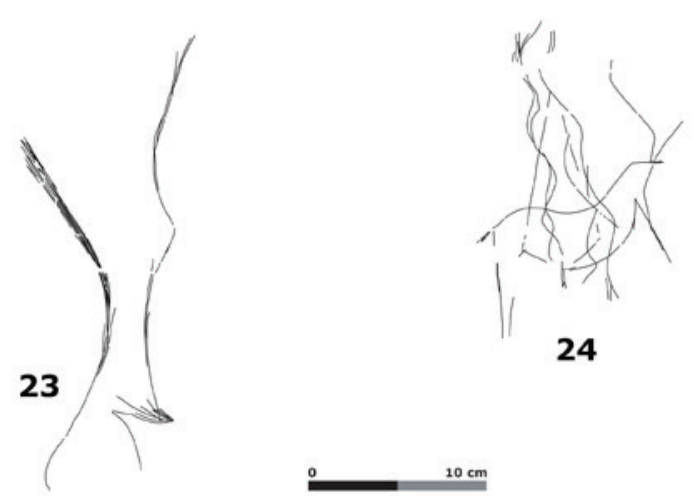

21(28)
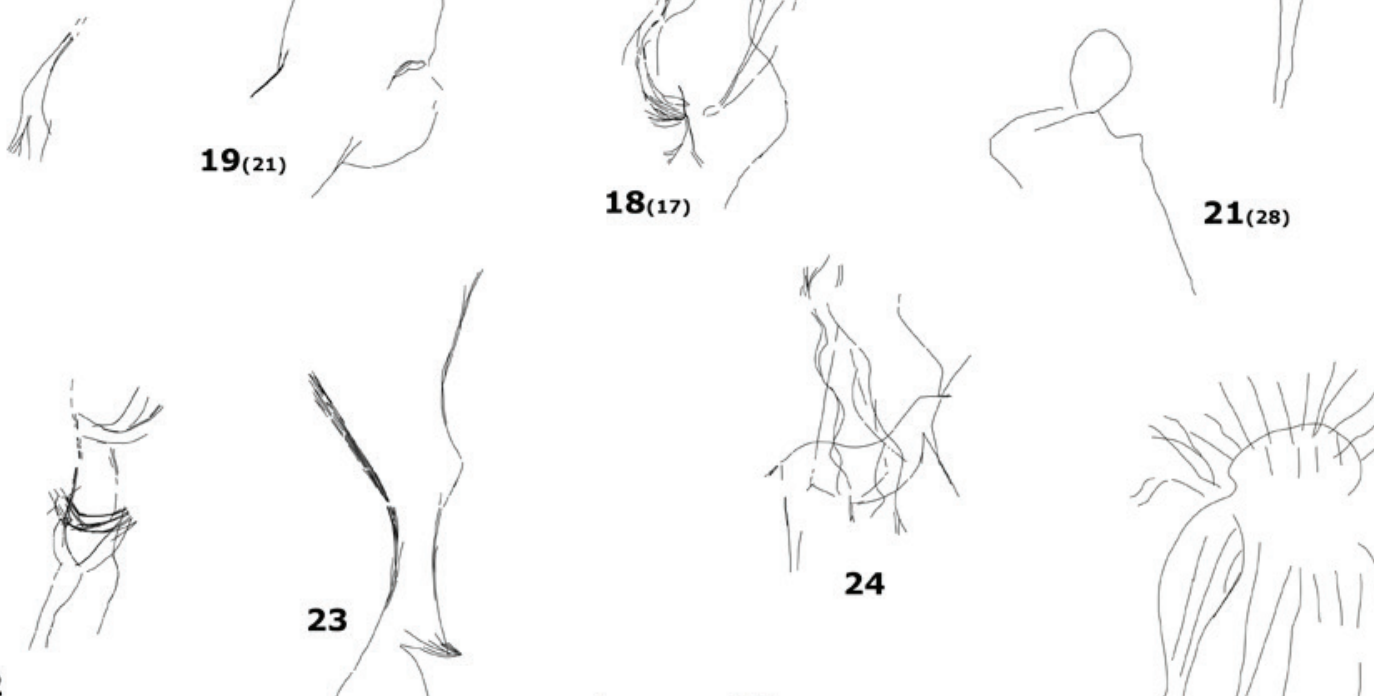

25

Figura 2 - Antropomorfos Paleolíticos de Tipo I. 1 - Ribeira de Piscos 2; 2 a 21 - Ribeira de Piscos 24 (entre parêntesis indica-se o número do painel); 22 e 23 - Fariseu 4; 24 - Fariseu 8; 25- Arte móvel do Fariseu (peça 4). Todos os desenhos são do PAVC/ CNART/Fundação Côa Parque, excepto o n⿳o 24, feito pelo autor a partir de fotografia. Todas as figuras foram reduzidas à mesma escala, excepto a n⿳o 25 , aumentada 5 vezes em relação a essa escala. 

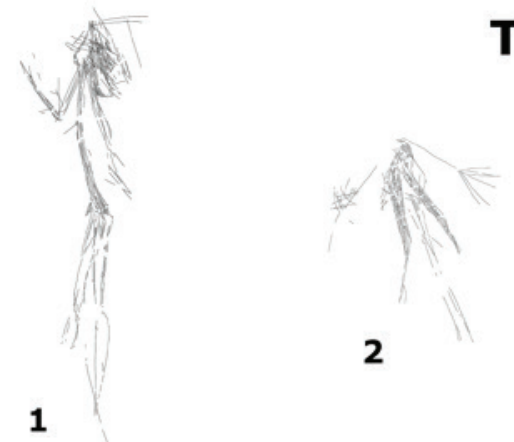

Tipo II

6

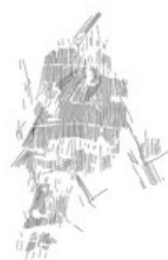

7
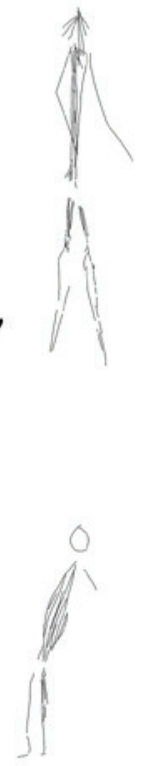

10

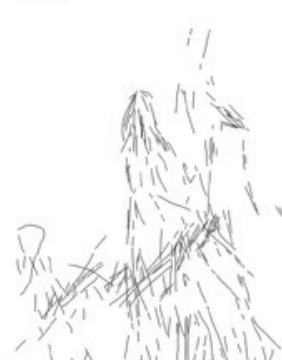

3

N.

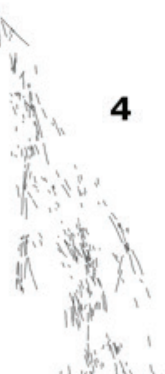

5

8
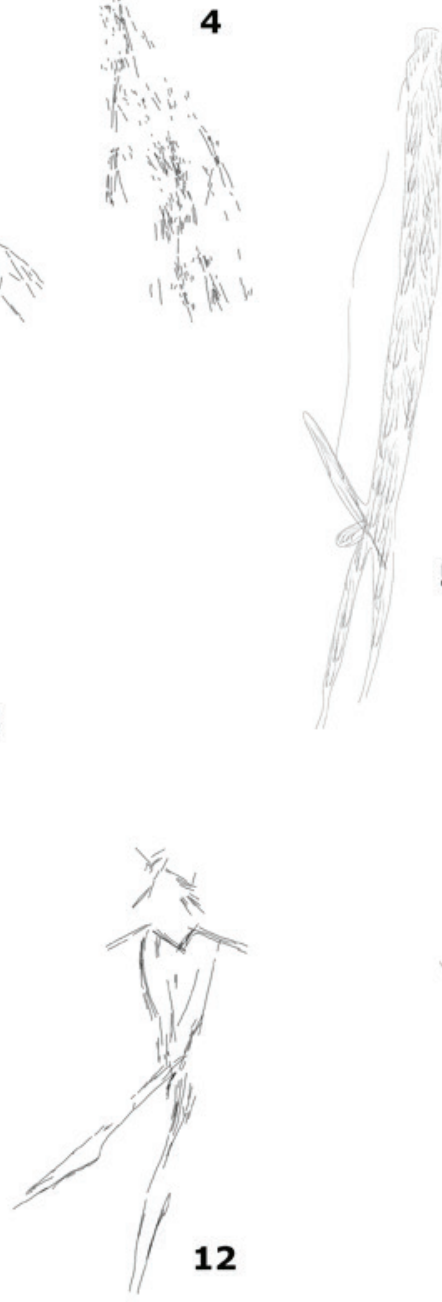

12

9

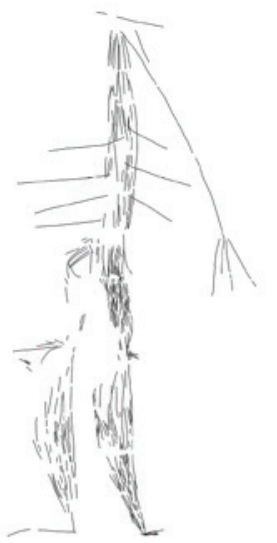

14

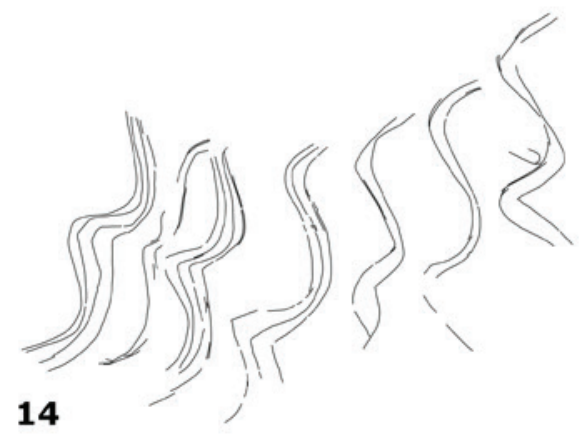

\section{Tipo III}




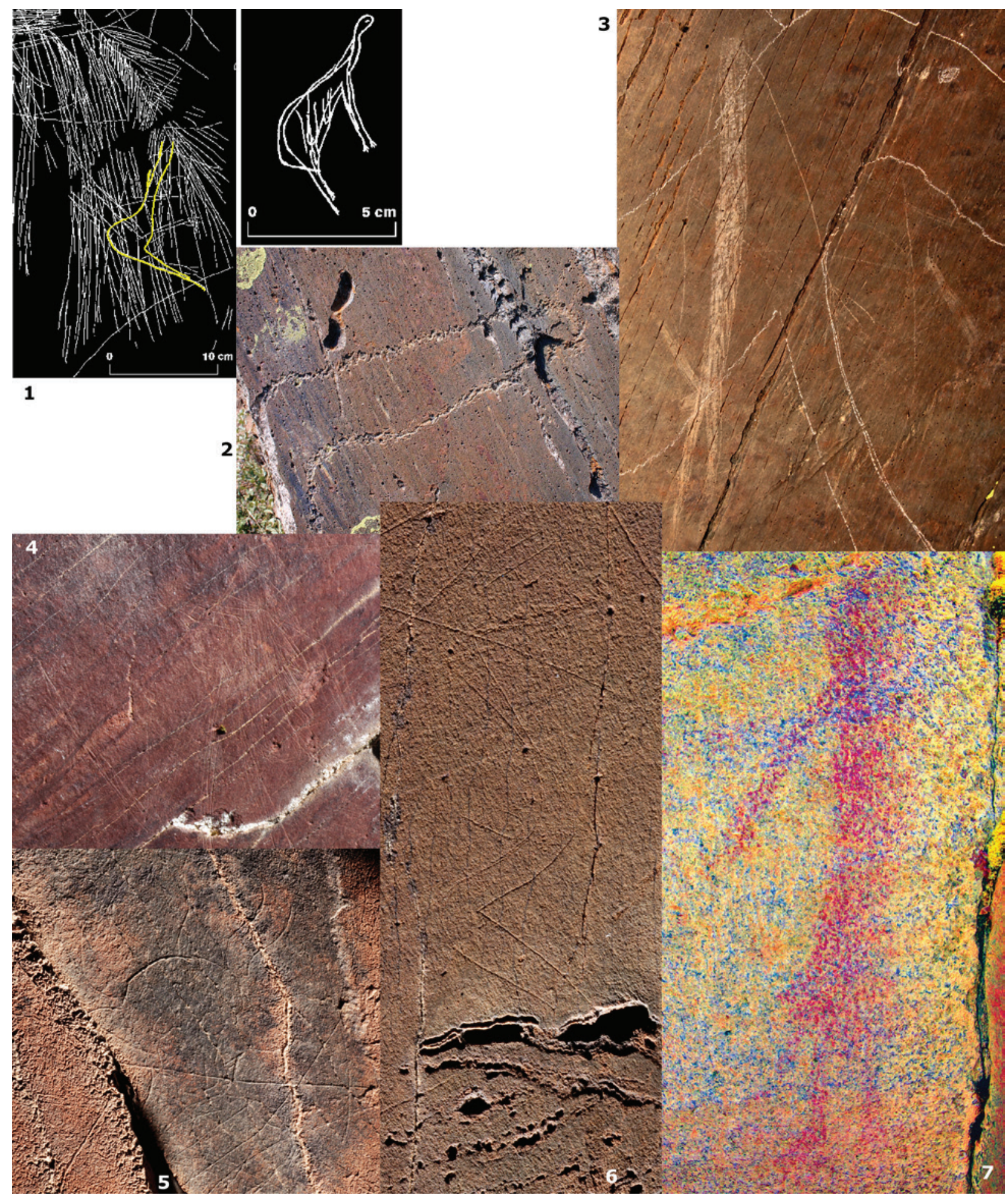

Figura 4 - Em cima, três exemplos de revisão cronológica de figuras: 1 - Vermelhosa 1 (a partir de Arcà, 1996); 2 - Quinta da Barca 18; 3 - Penascosa 17 (note-se o cervídeo Tardiglaciar à direita da mão do antropomorfo). Em baixo, exemplos diversos de figuras antropomórficas: 4 - Alto da Cotovia 2 (parte superior); 5-Ribeira de Piscos 24, painel 3 (detalhe da cabeça, notem-se os traços que emanam desta); 6 - Foz do Côa 148 (detalhe da figura na extremidade direita do conjunto); 7 - Ervideiro 2 (figura pintada possivelmente Epipaleolítica, talvez feminina, numa imagem tratada com DStretch). Todas as fotografias são do autor. 


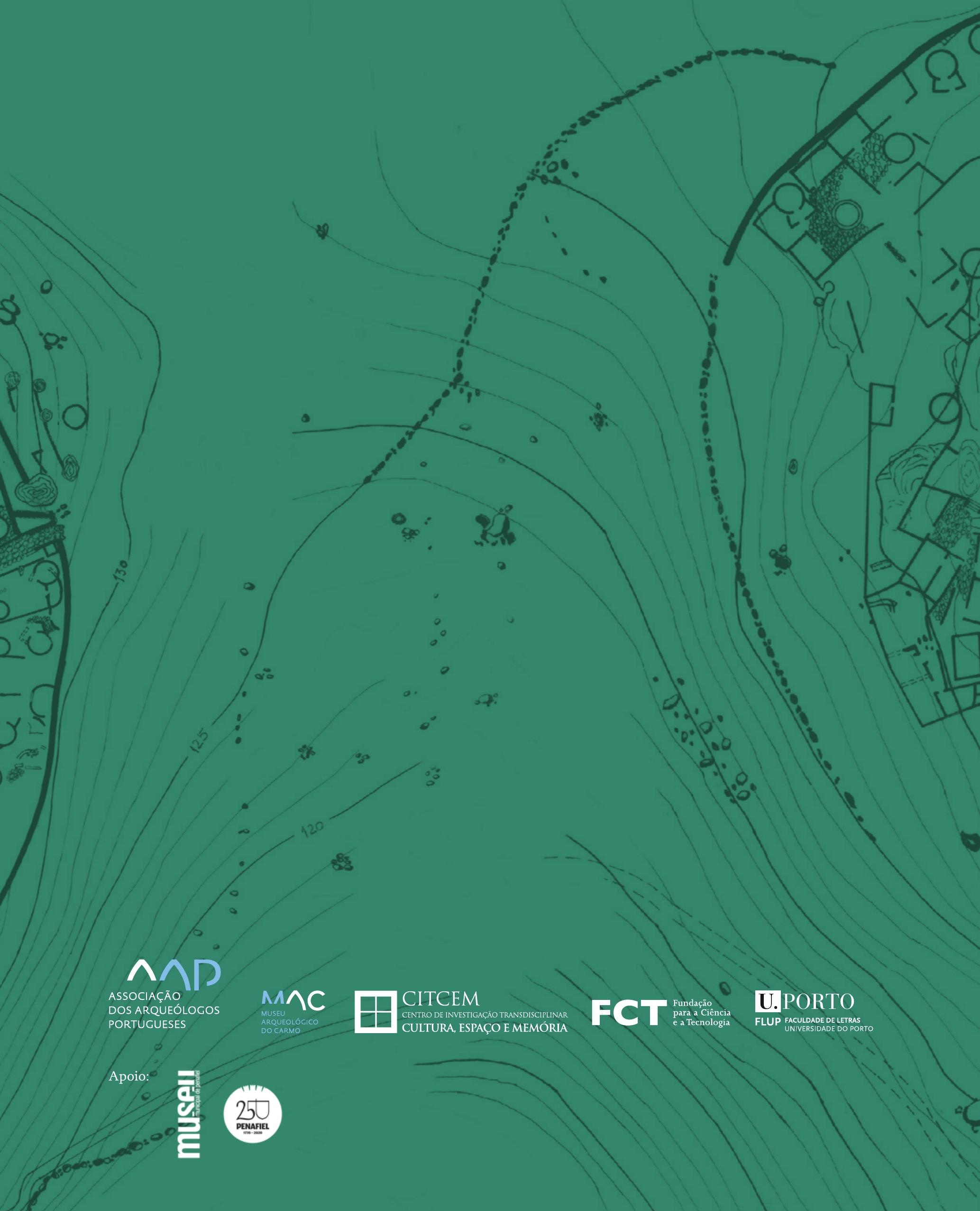

